\title{
Economic performance of forest-reliant census subdivisions between 1981 and 1991
}

\author{
by T. Williamson ${ }^{1}$, R. Samson ${ }^{2}$ and D. Korber ${ }^{1}$
}

This article assesses the economic performance of Canadian forest reliant census subdivisions (referred to as FRCs for the purposes of this paper) over the period 1981 to 1991. FRCs performed reasonably well over the 10 year period. The average annual rate of growth in base income was $1.7 \%$ per year. However, the performance of FRCs is quite varied. Growth of non-forest sectors was the major contributor to growth in FRCs indicating a general tendency for these CSDs to diversify and become less forest reliant over time. Generally, the FRCs that performed well over the period were the ones that initially had one or more of the following characteristics: larger FRCs, FRCs that were initially less forest reliant, FRCs with a higher paper and allied component in the forest sector and FRCs with lower initial wage rates.

Key words: forest reliant communities, sustainability of communities, economic indicators, economic performance, economic development, economic base, rural policy

\section{Introduction}

Providing stability and security for timber-dependent communities was one of the primary motivating factors for the introduction of sustained yield timber management policies at the turn of the century (Berck et al. 1992). Forest management objectives have subsequently diversified to consider a broader range of social objectives and values. Furthermore, community outcomes depend on a broad array of other, nonresource related factors. For example, communities are linked with other economies through various types of political, market, and civic institutions. Performance depends on internal factors (such as resource availability and local business capacity), external factors (such as trends in global markets), local institutions, and the ability of the community to adapt to external changes. This means that a sustainable timber supply does not guarantee community prosperity or stability (Byron 1978) nor does it necessarily contribute to the ability of the community to positively adapt and adjust to external changes. However, although community objectives do not dominate forest policy and social policy, they continue to be important considerations. The special circumstances and needs of resource-based communities are contributing to a renewed focus on their socioeconomic circumstances.

The unit of analysis in this study is the census subdivision (CSD) as defined by the Canada Census. The economies of

\footnotetext{
${ }^{1}$ Socioeconomic Research Network, Canadian Forest Service, 5320 - 122 St., Edmonton, Alberta T6H 3S5.

${ }^{2}$ Industry, Economics and Programs Branch, Canadian Forest Service, 580 Booth Street, Ottawa, Ontario. K1A 0E4.
}

Cet article détermine la performance économique des subdivisions de recensement canadiennes axées sur les ressources forestières (dénotées par SAF pour les besoins de cet article) pour la période 1981 à 1991. Les SAFs ont passablement bien performé au cours de la période de dix ans. Le taux annuel moyen de croissance du revenu de base fut de 1,7 \% par année. Néanmoins, la performance des SAFs fut très variée. La croissance des secteurs non-forestiers fut l'élément majeur de la croissance dans les SAFs, démontrant une tendance de ces SAFs à ce diversifier et devenir moins dépendants du secteur forestier au cours de la période observée. Généralement, les SAFs qui ont bien performé au cours de la période sont celles qui présentaient une ou plusieurs des caractéristiques suivantes: les grosses SAFs, les SAFs qui étaient initialement moins axées sur les ressources forestières, les SAFs avec une composante importante dans les pâtes et papier et les SAFs qui avaient des taux salariaux initialement bas.

Mots clés: collectivités axées sur les ressources forestières, durabilité des collectivités, indicateur économique, performance économique, développement économique, base économique, politique rurale

many Canadian CSDs are dominated by the forest product industry. For the purposes of this article these CSDs are referred to as "forest-reliant census subdivisions" or FRCs. Forest-reliant census subdivisions are subject to forces and influences that more diversified communities do not face to the same degree. They are more vulnerable to changes in the economic circumstances of individual firms, to sectoral business cycles, and to the overall competitiveness of a particular industry. They are vulnerable to changes in the availability, quality and cost of access of timber supply. ${ }^{3}$ They often lack political influence in decision-making and are therefore more vulnerable to changes in institutions and public policy than other communities. They are exposed to the influences of globalization, technological change, industrial restructuring and other socioeconomic trends such as the growing integration of rural and urban economies which in turn are reducing the adaptive capacity and resiliency of rural economic systems (Apedaile 1992). Finally, remoteness, distance from financial centres and services in urban centres and a lack of comparative advantage in alternative industry sectors provide barriers to financing new industrial development and diversifying the economic base of some forest-reliant communities. As a result of these influences, residents of some (although not necessarily all) FRCs face higher levels of economic uncertainty, instability, and limited alternatives when contraction or job loss through technolog-

\footnotetext{
${ }^{3}$ Although a secure timber supply in the vicinity of communities does not guarantee economic stability, reduced access to fibre, declines in wood quality, and/or increasing costs of accessing resources can have detrimental and destabilizing effects on economic performance.
} 
ical change occurs, which in turn can have detrimental effects on social conditions, health and welfare, and the ability of residents to accumulate wealth and savings.

The existence of FRCs or increases in the number of FRCs over time is neither a good thing nor a bad thing from a public policy perspective. What is relevant from a public policy perspective, however, is the economic and social welfare of the residents of these FRCs, which in turn is closely tied to the financial viability and profitability of firms in the dominant industry. Failure of firms and mill closures can have intense, negative, short term socioeconomic impacts on residents of undiversified communities ${ }^{4}$. At the same time, it is important to acknowledge that economic restructuring and mill closures are a natural economic phenomenon and are part of an ongoing competitive process of change.

The vulnerability of residents of FRCs and the social difficulties which may prevail in FRCs lead to normative questions concerning the role of public policy relative to these CSDs. What policies and regulations have the potential for unintended detrimental effects on FRCs and what changes are required to account for these effects? What can/should public policy do to prevent future drastic socioeconomic decline in FRCs at risk? What can/should public policy do to minimize the level of negative socioeconomic impacts and facilitate orderly transitions in FRCs that are currently in decline? What can/should public policy do to encourage positive economic development, diversification and future prosperity for residents of FRCs? An understanding of the effect of location on FRCs, their economic performance, and differences between growing and declining FRCs will help to identify economies that are in the process of undergoing drastic contraction, identify economies that face the possibility of drastic contraction (FRCs at risk), and provide general information about FRCs to support the development of rural policies.

This study identifies Canadian census subdivisions (CSDs) that were reliant on the forest products sector in 1981 and evaluates the economic performance of these CSDs over the ten year period 1981 to 1991 . The specific objectives are:

- to provide national and regional overviews of the economic performance of the sample of FRCs between 1981 and 1991.

- to identify differences in the characteristics of the sample of FRCs in various performance categories.

Two applications of the results of this analysis are: 1) to identify FRCs that underwent moderate to severe contraction between 1981 and 1991, and 2) to provide overall indicators of the economic performance of FRCs between 1981 and 1991. These are discussed in the applications section.

\section{The Approach for Evaluation of Economic Performance \\ Census subdivisions}

The data sources for the study are the 1981 and 1991 Censuses. Statistics Canada undertakes a major census of Canadian society at five-year intervals. In the last 20 -year period, censuses have been conducted in 1981, 1986, 1991, and 1996 (Note: employment and income data from the 1996 Census are scheduled to be released in 1998). Census data are available at various geographic scales (e.g., national, provincial, cen-

\footnotetext{
${ }^{4}$ The adoption of new technology by a firm can also result in job losses.
}

sus division, census subdivision, enumeration areas). The unit of measurement for the purpose of identifying FRCs is census subdivisions (CSDs). Statistics Canada defines CSDs as "the general term applying to municipalities (as determined by provincial legislation) or their equivalents, e.g., Indian Reserves, Indian settlements, and unorganized territories." (Statistics Canada 1992). Individual CSDs are identified by their name and a unique standard geographical classification (SGC) code. The variables extracted from 1981 Census for each CSD are population, employment ${ }^{5}$ (for each of 57 different industries), and average annual earned income per employee (for the same 57 industries). Identical variables are extracted from the 1991 Census.

There are a number of different types of CSDs including cities, towns, villages, counties, parishes, improvement districts, and others. CSDs include urban and rural communities as well as large rural areas with dispersed populations. However, this study does not differentiate or restrict the analysis to particular CSD types. Therefore, the 1981 FRCs include various types of CSDs, including cities, towns, and rural areas with dispersed populations.

\section{Scope of the analysis}

This study provides an assessment of the economic performance of 1981 FRCs by measuring the total size of the economic base in FRCs in two time periods (1981 and 1991) and the contribution of the forest products sector ${ }^{6}$ to the economic base of FRCs in the same two time periods. Relative changes in the size of the total economic base (in constant dollars) over the ten-year period provide an indication of the economic performance of these communities. Relative changes in the contribution of the forest products sector to the economic base of FRCs provides an indication of changes in the role of the forest industry in these CSDs over time.

The period of analysis for this study (1981 to 1991) is a short period of time relative to the long-term impacts of incremental changes in the structure of the forest products sector and the higher-order economy within which FRCs are situated. A period of time at least as long as the amortization period of a major capital investment (such as a pulp mill) would more completely reflect investment patterns in forest-based communities. However, long-term time series data are not available. The ten-year period that is the basis for this study will provide some preliminary indications of trends in the performance of FRCs.

\section{The economic base model}

The first step in assessing the performance of FRCs between two periods (1981 and 1991) is to identify CSDs where the forest sector is the dominant economic activity within the local economy in the first period (1981). Estimating the "eco-

\footnotetext{
${ }^{5}$ The employment number is based on the experienced labour force within the community. The 1991 Census definition of the experienced labour force is "persons who, during the week prior to June 4, 1991, were employed or unemployed but who had worked since January 1990."

${ }^{6}$ The forest products sector includes logging, forestry services, wood industries, and paper and allied industries. It does not isolate the contribution of other non-timber (but forest-based) economic activities such as tourism, hunting, and fishing to the local economy nor does it consider the importance of the forest to community residents in terms of subsistence uses, spiritual or cultural importance.
} 
nomic base" of a local economy and the contribution of a sector to the economic base is generally accepted as a practical approach for evaluating the contribution and importance of a sector to a local economy (Brown et al. 1992) ${ }^{7}$. The economic base of a local economy constitutes all economic activity associated with the production of goods and/or services which result in money being injected into the economy from external sources. Therefore, industries that produce and sell some, or all of their goods and services to non-residents constitute the base sector. Various economic measures can be used to measure the economic base, including employment, employment income, value of shipments, and value-added. This study measures the economic base in terms of employment income. Other potential sources of income injections into a local economy include investment earnings, payments to retirees, and social transfers. These latter categories of income injections are not included in the estimates of the economic base.

Schallau et al. (1969) were among the first to apply an economic base model for the purpose of identifying communities where the forest sector dominated the local economy. Fletcher et al. (1991) were among the first to apply an economic base modelling approach to assess the contribution of the forest sector to communities in Canada. Their study focussed on the prairie provinces ${ }^{8}$. Horne and Penner (1992) also applied an economic base model approach to identify forest-based communities in British Columbia. Williamson and Annamraju (1996) assessed the contribution of the forest sector to the economic base of all 6006 census subdivisions in the 1991 Census. The latter two studies use employment income to measure the economic base of CSDs. Fletcher et al. (1991) used employment as the unit of measurement. Details on the specific methodological design for determining the economic base in this study are provided in Williamson and Annamraju (1996).

\section{Sample determination}

The economic base model is initially applied to all 1981 census subdivisions (CSDs) with a population greater than 1000 persons. CSDs where the forest sector accounted for $50 \%$ or more of the economic base in 1981 are identified. Since there were changes in the boundaries of some CSDs between 1981 and 1991, the next step is to select 1981 FRCs where the boundary of the CSD had not changed significantly between 1981 and 1991 and reject those FRCs where the boundary had changed significantly. CSDs that were forest-reliant in 1981 but where the name had changed in 1991 are rejected. CSDs where the name remained the same but the SGC code changed are evaluated on the basis of population change (a change in SGC code meant possible adjustments in the boundary of the CSD between the two periods). CSDs where the population changed less than $50 \%$ between 1981 and 1991 are retained in the sample. CSDs where population change exceeded $50 \%$ are rejected. Figure 1 shows that a total of 249 census subdi-

\footnotetext{
${ }^{7}$ See Richardson (1985) for a review and discussion of economic base models and Power (1995) for a discussion of some of the limitations of an economic base approach. Also, an overview of the limitations and interpretive considerations of this study is available from the authors on request. ${ }^{8}$ This study also identified some underlying limiting assumptions of economic base models applied over a broad sample of communities. They include the assumptions of zero net exports, constant consumption patterns, constant productivity, and homogeneous products produced by industry classes. The study advanced some approaches to compensate for these limitations.
}

visions (out of a total of 5710) had a population of greater than 1000 persons and a forest reliance index greater than $50 \%$ in 1981. Twenty seven 1981 FRCs can not be matched with CSDs from the 1991 Census and are rejected from the sample. The remaining 222 CSDs provide the sample of FRCs for the purpose of this analysis. The economic base model is then applied to the 222 CSDs using the 1991 Census data. The model provides measures of total base income in nominal dollars (i.e., 1981 and 1991 dollars). Therefore, it is necessary to adjust the 1981 and 1991 measures of income to constant dollars. Income measures are adjusted to constant 1986 dollars using the GDP implicit price index (Statistics Canada 1996).

\section{Assessment framework}

A four-quadrant graph is used to stratify FRCs into four performance classes: Quadrant 1 - community income ${ }^{9}$ growth/ forest sector income growth, Quadrant 2-community income decline / forest sector income growth, Quadrant 3 - community income decline / forest sector income decline and Quadrant 4 - community income growth/forest sector income decline (see Fig. two). A similar analytical framework was used by Clemenson (1992) to assess changes in fishing, forestry and mining towns between 1981 and 1986. Individual FRCs are plotted on the graph in terms of percentage change in total base income (constant 1986 dollars) (Y axis) and percentage change in forest income (constant 1986 dollars) (X axis).

One graph is provided at the national level for all 222 FRCs (Fig. 2). The diagonal line on Fig. two represents points where change in forest sector base income is equal to change in total community base income. All FRCs above the diagonal line became less reliant on the forest sector between 1981 and 1991. A separate set of graphs is provided for various provinces and regions to provide regional overviews (Fig. 3 -7). Regional graphs are provided for Atlantic Canada, Quebec, Ontario, prairie provinces, and B.C. Quadrant, region$\mathrm{al}$, and national averages of percentage change in the total economic base and percentage change in forest base income are derived.

To determine if there are distinguishing features between successful FRCs and declining FRCs, quadrant averages are derived for four variables, including average population (to represent size), average income (per labour force participant), average degree of forest reliance, and average percentage of forest base income contributed by the paper and allied sector. In some cases the averages are provided for both 1981 and 1991 to assess changes.

\section{Economic Performance of FRCs Between 1981 and 1991 \\ National overview}

Figure 2 provides an overview of the economic performance of the 222 FRCs (which constitute the sample) over the tenyear period 1981 to 1991 . Overall, the economies of FRCs had positive economic base growth between 1981 and 1991, but this seems to be the result of growth in non-forest related economic sectors in these FRCs. The economic base increased (in constant 1986 dollars) in 150 (or $68 \%$ ) of the 222 FRCs. How-

\footnotetext{
${ }^{9}$ Community income refers to economic base sector income in this article.
} 


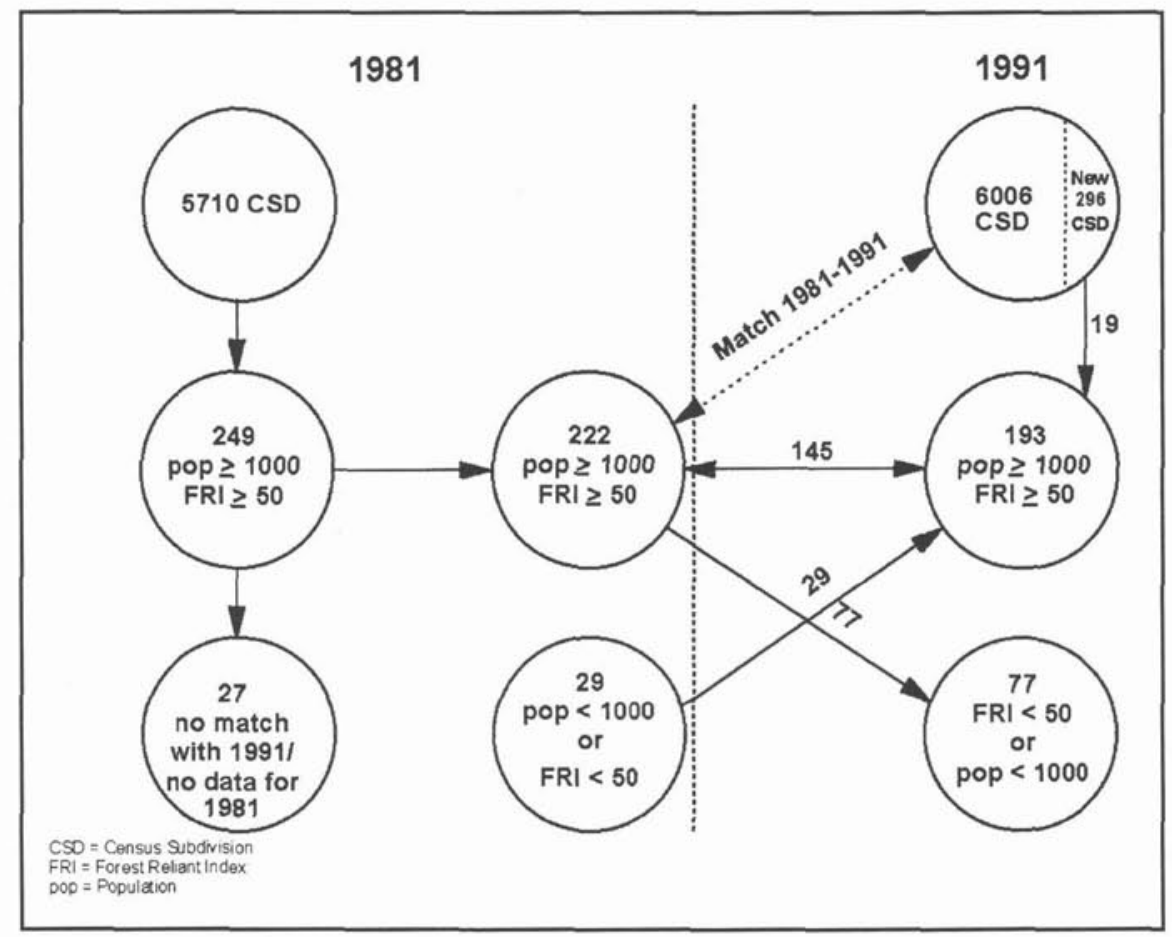

Fig. 1. Determination of the sample size for assessing economic performance. Source: Canadian Forest Service.

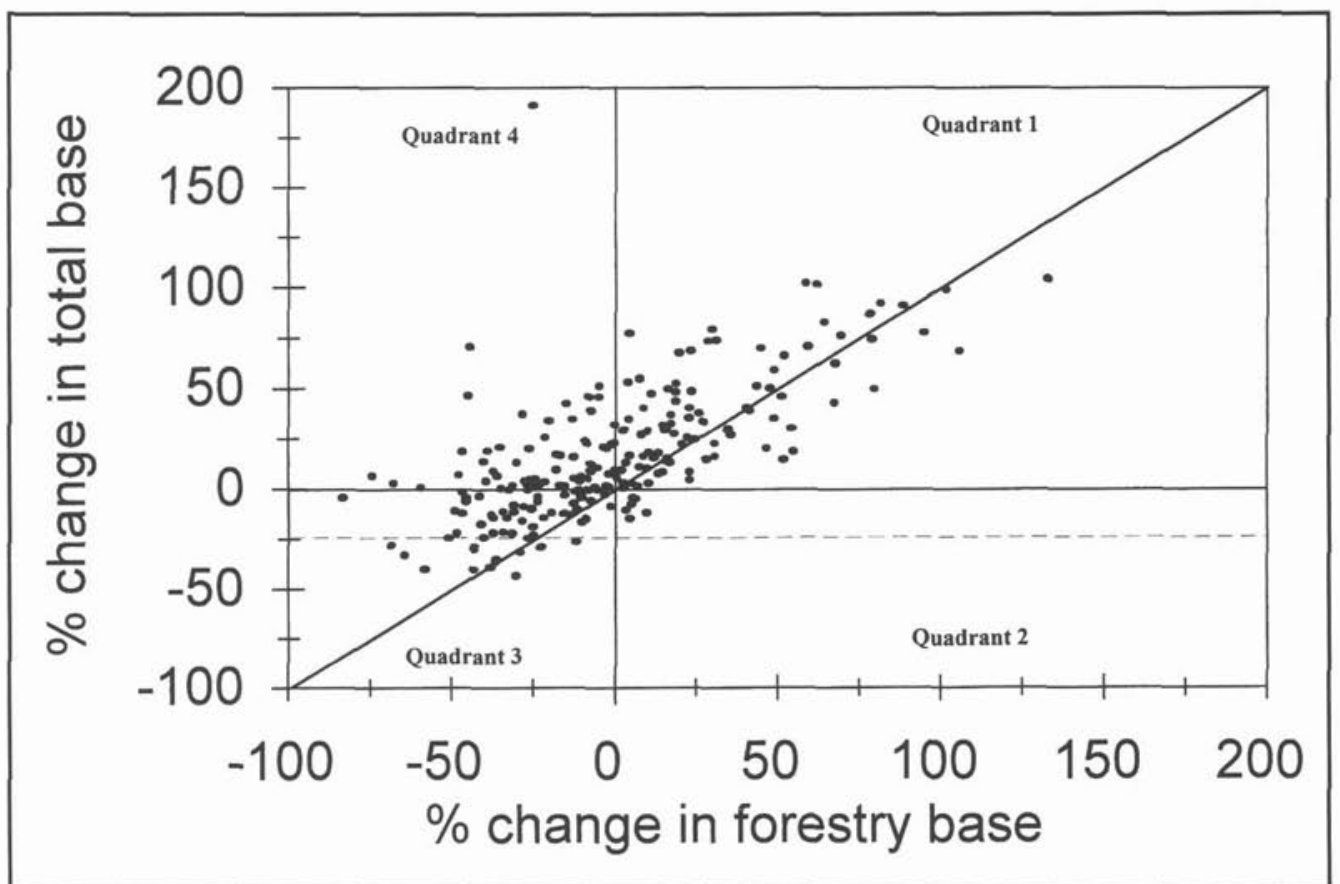

Fig. 2. Percent change in the size of the total economic base and in forest sector base income for 222 forest-reliant communities between 1981 and 1991: Canada overview. Source: Canadian Forest Service.

ever, forest sector base income declined in 125 (or 56\%) of the CSDs. ${ }^{10}$

\footnotetext{
${ }^{10}$ Total real income paid to employees of the forest products industry in FRCs declined by $1.2 \%$ between 1981 and 1991 (Table 1). However, the total value of wages paid by the Canadian forest products industry increased by $14 \%$ between 1981 and 1991 ( $\$ 6.3$ billion to $\$ 7.2$ billion in constant 1991 dollars)(Canadian Forest Service 1996). Therefore, the decline in forest base income in FRCs was not due to a general decline in wage payments by the forest industry.
}

One hundred and seventy-six (79\%) of the FRCs are situated above the diagonal line. FRCs above the diagonal line in Quadrant 1 were able to attract new export-based business into the community or develop and expand local export-based businesses at a rate that exceeded growth in the forest sector. Forest products sector base income declined in Quadrant 4. However, the total economic base income of the FRCs grew despite these declines. Quadrant 4 FRCs were able to attract 


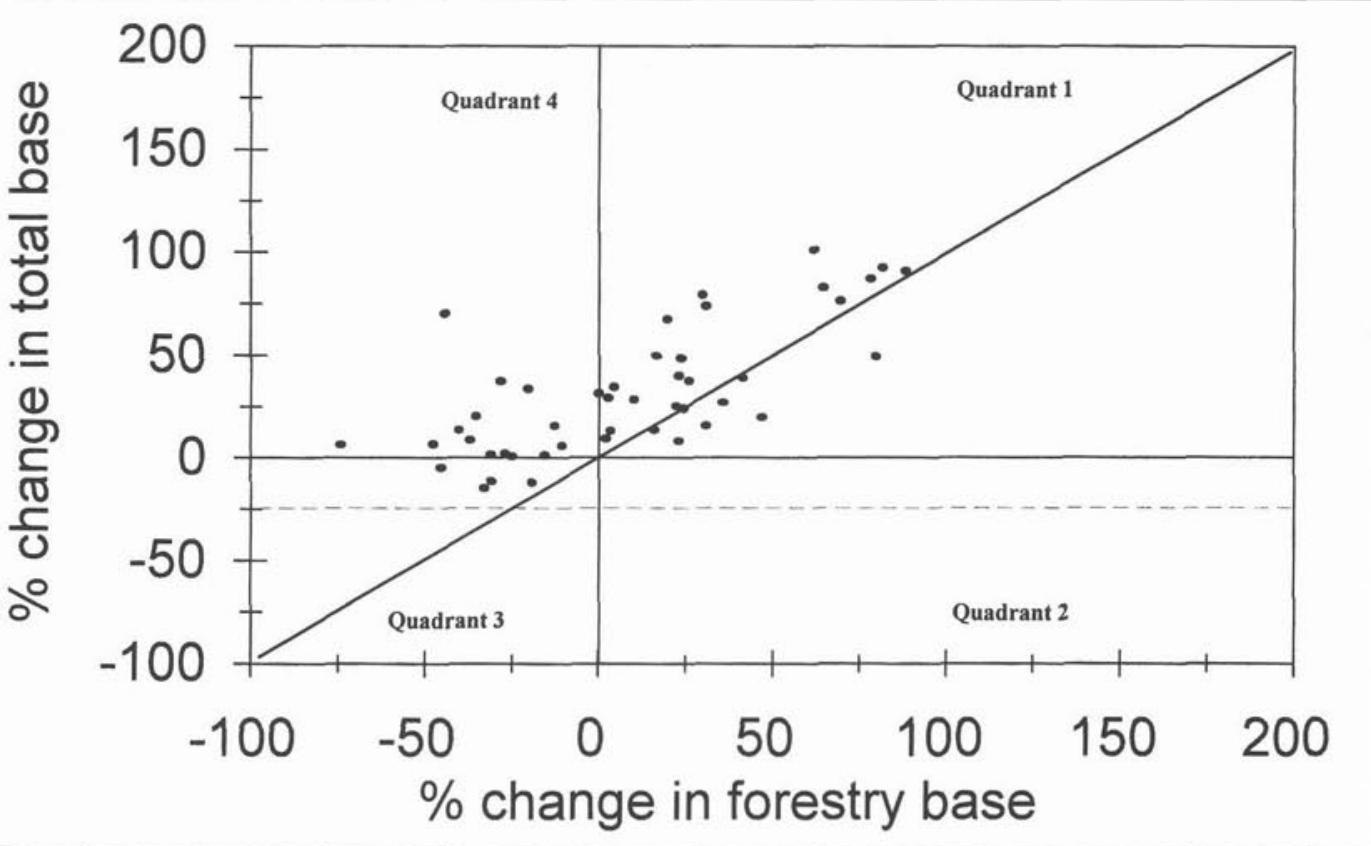

Fig. 3. Percent change in the size of the total economic base and in forest sector base income for 46 forest-reliant communities between 1981 and 1991: Atlantic region summary. Source: Canadian Forest Service.

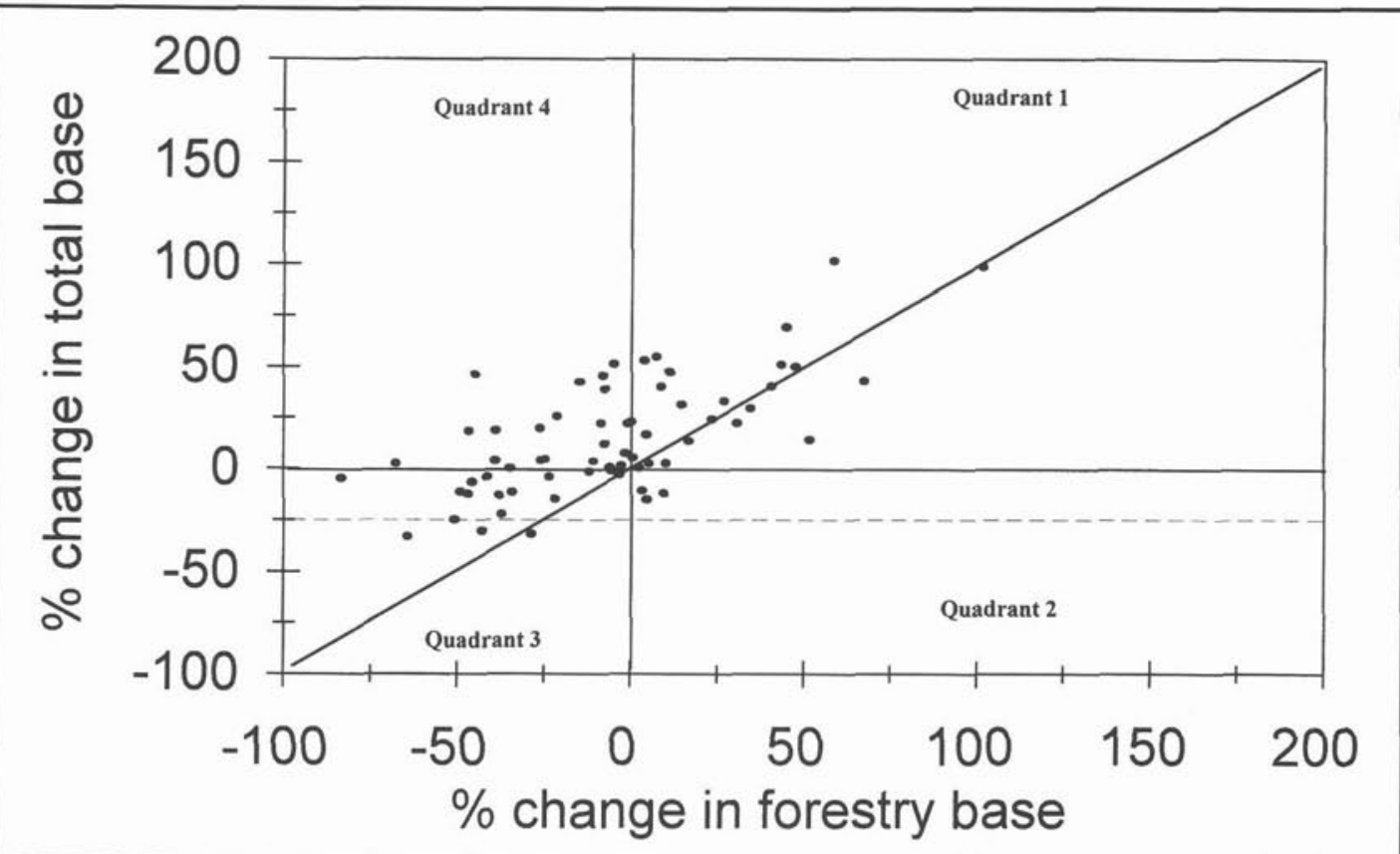

Fig. 4. Percent change in the size of the total economic base and in forest sector base income for 65 forest-reliant communities between 1981 and 1991: Quebec summary. Source: Canadian Forest Service.

new non-forest, export-based businesses or develop and expand local non-forest, export-based businesses at a rate that exceeded the decline in forest sector base income. In Quadrant 3 , both forest income and total community income declined. CSDs above the diagonal line in this quadrant are FRCs where non-forest sectors either a) declined to a lesser degree than in the forest sector, b) were stable over the period, or c) increased but not enough to totally offset the loss in forest sector base income.
The results provided in Fig. 2 also identify FRCs where decline was relatively extreme. The total economic base of 13 FRCs declined by over $25 \%$ between 1981 and 1991 (i.e., below the dashed line in Fig. 2). This rate of decline would have significant implications for living conditions, social conditions, household incomes, and personal savings within these FRCs. It also has implications for increased dependence on social income support programs. These FRCs are discussed in more detail in the "Applications" section. 


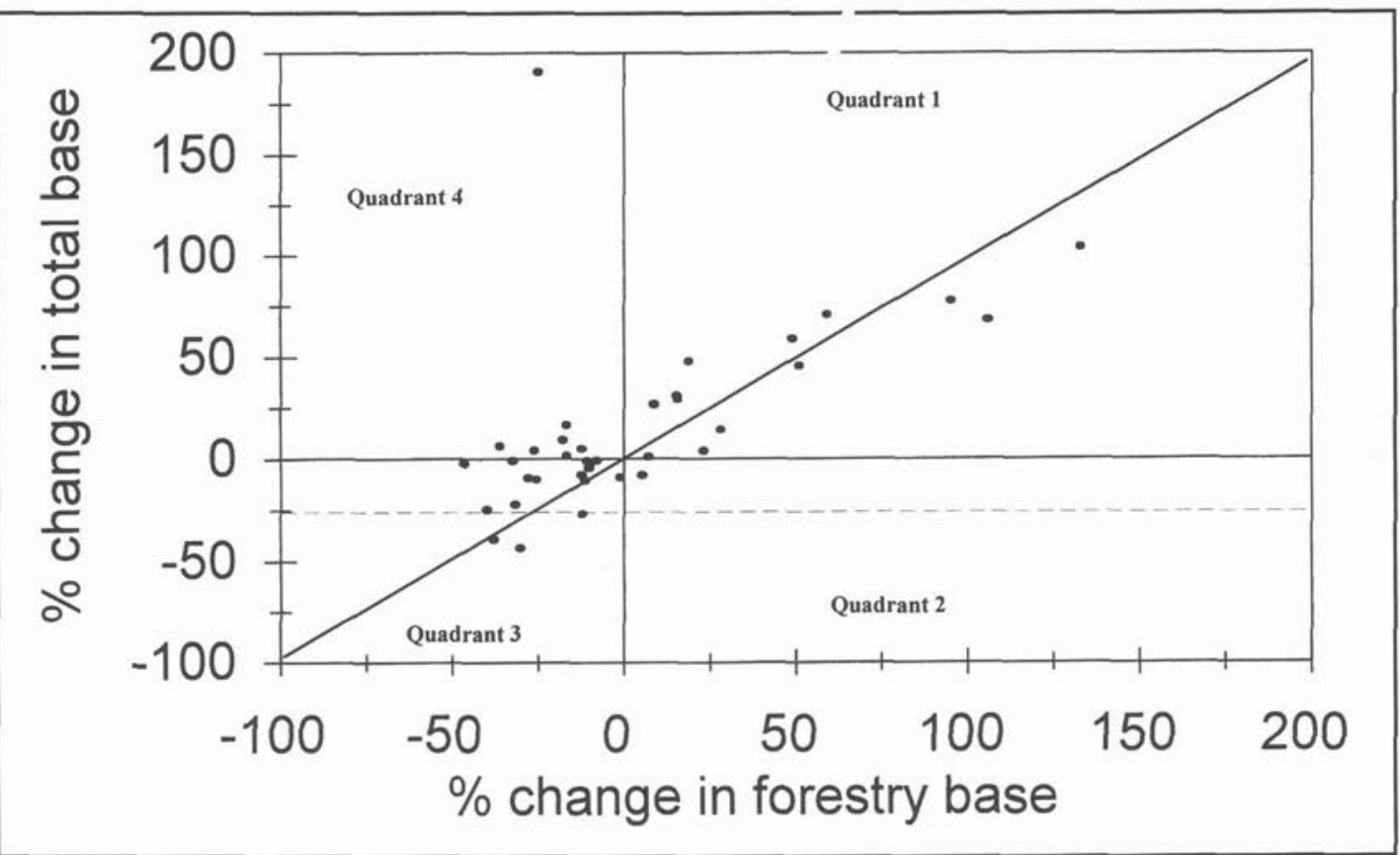

Fig. 5. Percent change in the size of the total economic base and in forest sector base income for 37 forest-reliant communities between 1981 and 1991: Ontario summary. Source: Canadian Forest Service.

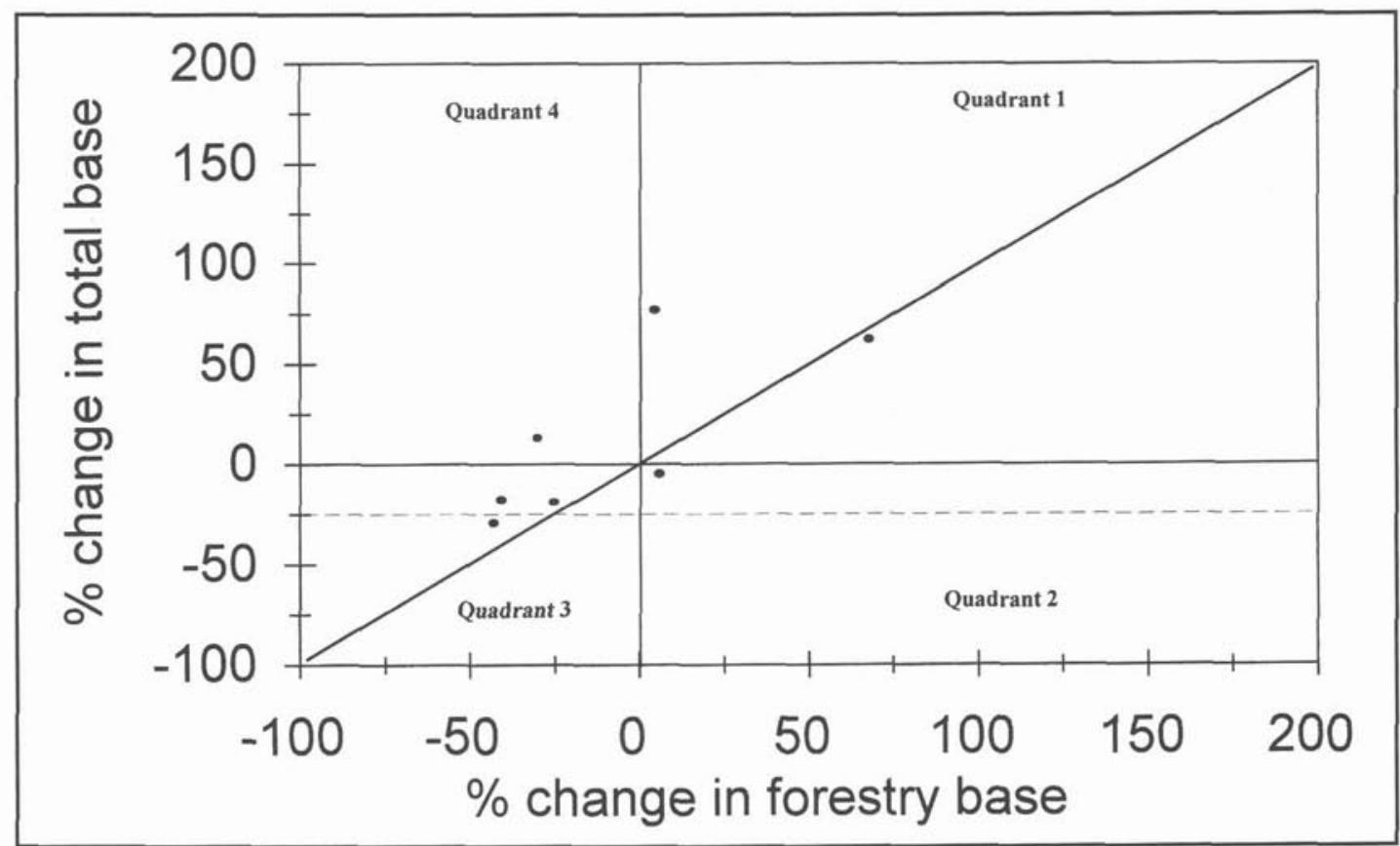

Fig. 6. Percent change in the size of the total economic base and in forest sector base income for 7 forest-reliant communities between 1981 and 1991: Prairie region summary. Source: Canadian Forest Service.

\section{Regional results}

The results provided in Fig. 2 provide a national overview. However, there are regional differences in the performance of FRCs. The following provides regional information on the economic performance of FRCs.

Figure 3 provides information on the performance of the 46 FRCs in Atlantic Canada between 1981 and 1991. FRCs in this region performed better than any other region. The average annual percent change in the economic base of FRCs was $3.2 \%$ per year (Table 1) between 1981 and 1991. The economies of $91 \%$ (Table 2) of the FRCs in this region increased between 1981 and 1991 and of the four FRCs where the economic base declined, none declined more than $25 \%$ (Table 3 ). The majority of the FRCs ( $59 \%$ ) were situated in Quadrant 1 (27 FRCs) meaning growth in the economies of these FRCs is associated with growth in the forest products sector. However, the nonforest economic base sectors also performed well between 1981 and 1991. On average, the relative contribution of the forest 


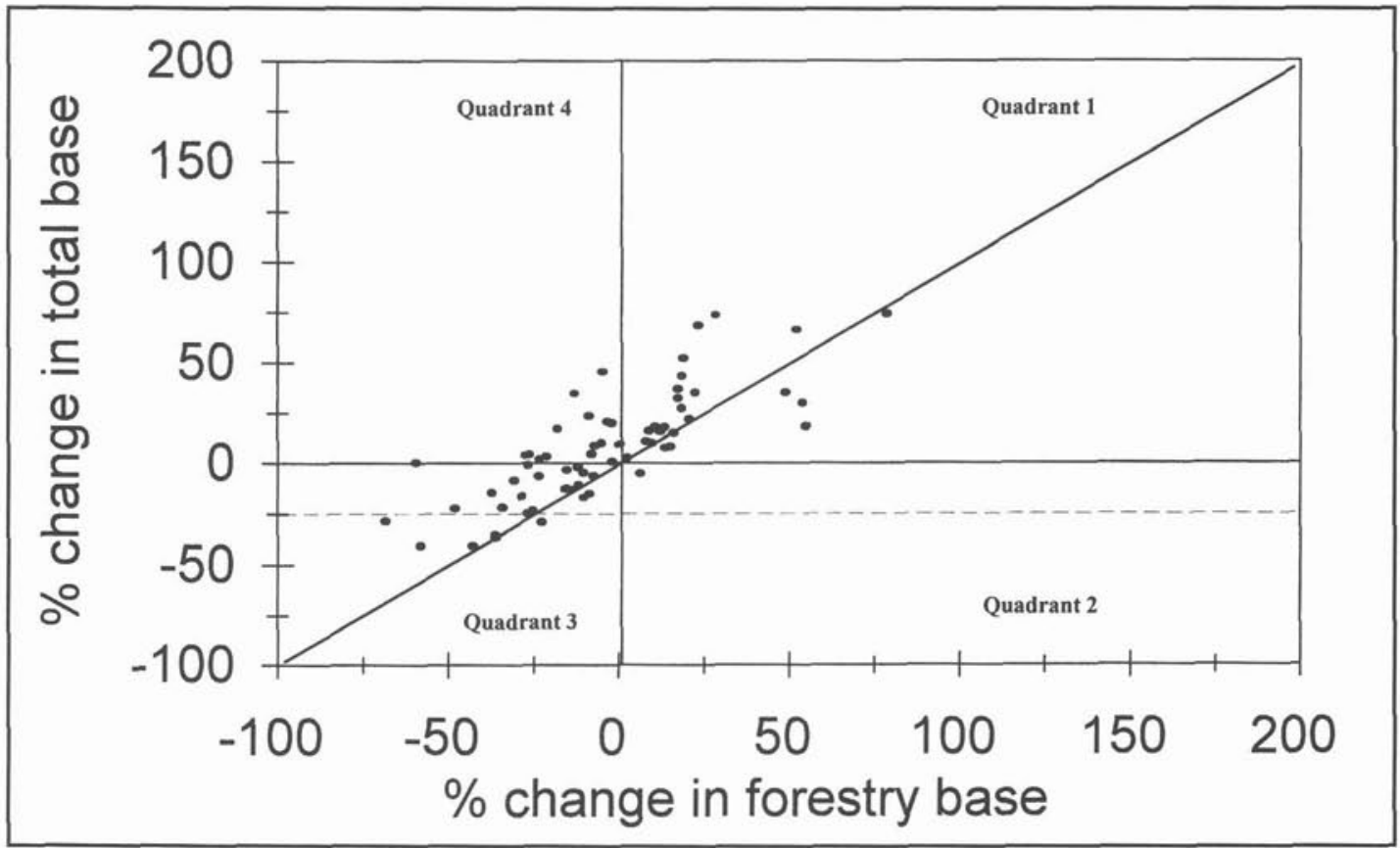

Fig. 7. Percent change in the size of the total economic base and in forest sector base income for 67 forest-reliant communities between 1981 and 1991: British Columbia summary. Source: Canadian Forest Service.

Table 1. Average percentage change in total economic base versus average percent change in forest economic base between 1981 and 1991

\begin{tabular}{|c|c|c|c|c|c|c|c|c|c|c|}
\hline & \multicolumn{2}{|c|}{$\begin{array}{c}\text { Quadrant } \\
1\end{array}$} & \multicolumn{2}{|c|}{$\begin{array}{c}\text { Quadrant } \\
2\end{array}$} & \multicolumn{2}{|c|}{$\begin{array}{c}\text { Quadrant } \\
3\end{array}$} & \multicolumn{2}{|c|}{$\begin{array}{c}\text { Quadrant } \\
4\end{array}$} & \multicolumn{2}{|c|}{ Total } \\
\hline & 1981 & 1991 & 1981 & 1991 & 1981 & 1991 & 1981 & 1991 & 1981 & 1991 \\
\hline Atlantic & 47.1 & 35.5 & - & - & -10.6 & -32.2 & 17.3 & -29.9 & 32.3 & 8.3 \\
\hline Quebec & 36.3 & 27.5 & -12.4 & 6 & -13.2 & -36.9 & 18.8 & -21 & 15.5 & -6 \\
\hline Ontario & 44.8 & 46.9 & -7.7 & 5.2 & -13.1 & -21.8 & 33.7 & -21.5 & 16.3 & 3.1 \\
\hline Prairies & 69.9 & 36.1 & -4.4 & 5.7 & -21.8 & -36.4 & 13.2 & -29.9 & 11.9 & -8.7 \\
\hline B.C. & 30 & 23.4 & -4.9 & 6.4 & -17.4 & -26.2 & 13.6 & -15.3 & 7.4 & -4.8 \\
\hline All 222 communities & 39.7 & 31.7 & -9 & 5.9 & -15 & -28.7 & 18.8 & -22 & 16.6 & -1.2 \\
\hline
\end{tabular}

products sector to total economic base declined from $71 \%$ to $57 \%$ between 1981 and 1991 (Table 4).

Sixty-five of the 222 FRCs (1981 sample) were situated in the province of Quebec (Table 2). Sixty-nine percent of Quebec FRCs experienced growth between 1981 and 1991 (Fig. 4 and Table 2). The average annual rate of economic base income growth in FRCs between 1981 and 1991 was 1.5\% (Table 1), which was slightly below the national average annual rate of $1.7 \%$. This growth occurred despite the fact that forest income declined on average $0.6 \%$ per year (forest sector base income declined $0.1 \%$ per year for all 222 CSDs). Quadrant 1 FRCs (24 FRCs) experienced an annual growth rate of $3.6 \%$ while Quadrant 3 FRCs (17 FRCs) declined an average annual rate of $1.3 \%$. Three Quebec FRCs suffered declines exceeding 25\% over the ten-year period (Table 4).

Ontario's FRCs (which totalled 37) seem to be more sensitive to changes in forest base income. The Ontario FRCs exhibit a higher level of clustering around the diagonal line than FRCs in other regions (Fig. 5) + especially in Quadrant 1. This means that changes in community income are more closely related to changes in forest base income than in other regions. In fact, the level of forest reliance actually increased slightly in Quadrant 1 FRCs between 1981 and 1991 (Table 4). Ontario is the only region where this occurred in Quadrant 1 . The overall performance of Ontario's FRCs $(1.6 \%$ average annual growth) was a distant second to Atlantic Canada FRCs (3.2\% growth). However, Ontario FRCs had the highest rate of growth in forest base income (4.7\% a year) in Quadrant 1 (14 FRCs) and the lowest average rate of decline in forest base income ( $2.2 \%$ a year) in Quadrant 3 (16 FRCs) (Table 1). This suggests a higher propensity for Ontario FRCs to attract new forestry investment and a lower propensity for forest industry downsizing than other regions. Three Ontario FRCs suffered declines exceeding $25 \%$ between 1981 and 1991 (Table 3).

There were only 7 FRCs in the prairie provinces sample in 1981 (Fig. 6). This is in stark contrast to the Atlantic region, which contains a similar-sized forest products sector but had $46 \mathrm{FRCs}$ in $1981^{11}$. This suggests that forest products processing centres in the prairies are more generally associated with more economically diversified communities. However, the issue of forest reliance is still of relevance to the prairie region. The

\footnotetext{
${ }^{11}$ The volume of roundwood harvested in the prairie region in 1981 was $11944000 \mathrm{~m}^{3}$. The volume of roundwood harvested in the Atlantic region in 1981 was $14846000 \mathrm{~m}^{3}$. (National Forestry Database Program 1997).
} 
Table 2. Regional distribution of the 2221981 forest-reliant communities by performance category

\begin{tabular}{|c|c|c|c|c|c|c|c|c|c|c|}
\hline & \multicolumn{2}{|c|}{$\begin{array}{c}\text { Quadrant } \\
1 \\
\end{array}$} & \multicolumn{2}{|c|}{$\begin{array}{c}\text { Quadrant } \\
2\end{array}$} & \multicolumn{2}{|c|}{$\begin{array}{c}\text { Quadrant } \\
3\end{array}$} & \multicolumn{2}{|c|}{$\begin{array}{c}\text { Quadrant } \\
4\end{array}$} & \multicolumn{2}{|c|}{ Total } \\
\hline & $\#$ & $\%$ & $\#$ & $\%$ & \# & $\%$ & $\#$ & $\%$ & \# & $\%$ \\
\hline Atlantic & 27 & 58.7 & - & - & 4 & 8.7 & 15 & 32.6 & 46 & 100 \\
\hline Quebec & 24 & 36.9 & 3 & 4.6 & 17 & 26.2 & 21 & 32.3 & 65 & 100 \\
\hline Ontario & 13 & 35.1 & 1 & 2.7 & 16 & 43.2 & 7 & 18.9 & 37 & 100 \\
\hline Prairies & 2 & 28.6 & 1 & 14.3 & 3 & 42.9 & 1 & 14.3 & 7 & 100 \\
\hline B.C. & 25 & 37.3 & 1 & 1.5 & 26 & 38.8 & 15 & 22.4 & 67 & 100 \\
\hline Total & 91 & 41 & 6 & 2.7 & 66 & 29.7 & 59 & 26.6 & 222 & 100 \\
\hline
\end{tabular}

Table 3. Distribution of communities by degree of change in the economic base between 1981 and 1991

\begin{tabular}{|c|c|c|c|}
\hline & $\begin{array}{c}\text { Communities where base } \\
\text { income declined by more } \\
\text { than } 25 \% \\
\#\end{array}$ & $\begin{array}{c}\text { Communities where base } \\
\text { income changed between } \\
-25 \% \text { and }+25 \% \\
\#\end{array}$ & $\begin{array}{c}\text { Communities where base } \\
\text { income grew by more than } \\
25 \% \\
\#\end{array}$ \\
\hline Atlantic & - & 22 & 24 \\
\hline Quebec & 3 & 42 & 20 \\
\hline Ontario & 3 & 23 & 11 \\
\hline Prairies & 1 & 4 & 2 \\
\hline B.C. & 6 & 47 & 14 \\
\hline Totals & 13 & 138 & 71 \\
\hline
\end{tabular}

Table 4. Average percentage of the total economic base of communities in the forest products sector: 1981 and 1991

\begin{tabular}{|c|c|c|c|c|c|c|c|c|c|c|}
\hline & \multicolumn{2}{|c|}{$\begin{array}{c}\text { Quadrant } \\
1\end{array}$} & \multicolumn{2}{|c|}{$\begin{array}{c}\text { Quadrant } \\
2\end{array}$} & \multicolumn{2}{|c|}{$\begin{array}{c}\text { Quadrant } \\
3\end{array}$} & \multicolumn{2}{|c|}{$\begin{array}{c}\text { Quadrant } \\
4\end{array}$} & \multicolumn{2}{|c|}{ Total } \\
\hline & 1981 & 1991 & 1981 & 1991 & 1981 & 1991 & 1981 & 1991 & 1981 & 1991 \\
\hline Atlantic & 70.6 & 64.8 & - & - & 68.8 & 52 & 73.2 & 45.3 & 71.3 & 57.3 \\
\hline Quebec & 70.3 & 66.7 & 65.7 & 79.3 & 65.6 & 48.7 & 69.6 & 47.8 & 68.6 & 56.5 \\
\hline Ontario & 63.1 & 63.5 & 54 & 61.6 & 82.4 & 75.8 & 67.3 & 42.6 & 72 & 64.8 \\
\hline Prairies & 52.5 & 42.7 & 58.4 & 64.6 & 80.9 & 65.9 & 59.9 & 37.1 & 66.6 & 55 \\
\hline B.C. & 71.7 & 68.6 & 59.2 & 66.2 & 75.4 & 67.5 & 65.8 & 49.8 & 71.6 & 63.9 \\
\hline All 222 communities & 69.3 & 65.7 & 61.4 & 71.7 & 74.4 & 63.7 & 69.1 & 46.9 & 70.6 & 60.2 \\
\hline
\end{tabular}

economic base of four of the seven FRCs in the prairie region declined over the ten-year period (Table 2). The economic base in the FRCs in Quadrant 3 (3 FRCs) declined by a dramatic $2.2 \%$ per year (Table 1 ). This was the most significant decline experienced in any region and it was associated with a sharp drop in forest base income ( $3.6 \%$ a year). One prairie province FRC suffered a decline of more than $25 \%$ in its economic base between 1981 and 1991.

The largest number of FRCs in the sample (67) were located in B.C. Fig. 7 and Table 2 show that the economies of most FRCs increased over the period; however, the overall rate of growth in B.C. FRCs $(0.7 \%$ per year) was less than the national average (1.7\%) and was also the lowest of the five regions considered. Quadrant 1 FRCs (25 FRCs) had the lowest rate of overall growth and the lowest rate of growth in forest base income of all regions (Table 1). Quadrant 3 FRCs (26 FRCs) had the second highest rate of decline but the second lowest rate of decline in forest base income. Quadrant 4 FRCs (15 FRCs) ranked fourth in terms of rate of growth in the economic base of FRCs but had the lowest rate of decline in forest base income (by a significant margin). These results point to two general findings. First, forest base income change was more stable in B.C. FRCs than in other regions (i.e., relatively modest forest base income growth in Quadrants 1 and 2 and modest forest base income declines in Quadrants 3 and 4). Sec- ond, B.C. FRCs appear to have a lower propensity to diversify and had a greater tendency to retain their reliance on the forest sector over the ten-year period. Table 4 shows that the percentage of the total economic base in the forest sector in 1991 in B.C. FRCs was the highest of all regions in every quadrant except the Quadrant 2 FRCs in Quebec (three FRCs) and the Quadrant 3 FRCs in Ontario (16 FRCs). Six B.C. FRCs experienced declines exceeding $25 \%$ of their economic base between 1981 and 1991.

Changes in FRC Status Between 1981 and 1991

Figure 1 shows that there were 222 FRCs in 1981 and 193 FRCs in 1991. The change in the total number of FRCs between 1981 and 1991 (i.e., a decline of 29) was due to a combination of three things. First, 77 CSDs which were forest-reliant in 1981 were non-forest-reliant in 1991. Second, 29 CSDs which were non-forest-reliant in 1981 became forest-reliant in 1991. Third, of the 296 CSDs which were added to the 1991 Census (and which had no equivalent match in 1981), 19 were forest-reliant in 1991. The net effect of these trends was that there was a decline of 29 in the absolute number of FRCs between 1981 and $1991(222-77+29+19=193)$. This observation is of interest because it shows that forest reliance may only be a temporary condition in many communities. 
Table 5. Summary table of measures characterizing FRCs by quadrant

\begin{tabular}{|c|c|c|c|c|c|}
\hline & Quadrant 1 & Quadrant 2 & Quadrant 3 & Quadrant 4 & Total \\
\hline Change in community economic base & increasing & decreasing & decreasing & increasing & \\
\hline Change in forest base income & increasing & increasing & decreasing & decreasing & \\
\hline Number of communities & 91 & 6 & 66 & 59 & 222 \\
\hline$\%$ of communities & $41.0 \%$ & $2.7 \%$ & $29.7 \%$ & $26.6 \%$ & $100.0 \%$ \\
\hline Average population (1981) & 4708 & 3269 & 4296 & 6920 & 5134 \\
\hline Average forestry-reliant index in 1981 & $69.3 \%$ & $61.4 \%$ & $74.4 \%$ & $69.1 \%$ & $70.6 \%$ \\
\hline Average forestry-reliant index in 1991 & $65.7 \%$ & $71.7 \%$ & $63.7 \%$ & $46.9 \%$ & $60.2 \%$ \\
\hline $\begin{array}{l}\text { Average\% of forestry base income in the paper and } \\
\text { allied sector (1981) }\end{array}$ & $40.9 \%$ & $41.9 \%$ & $29.9 \%$ & $39.1 \%$ & $37.7 \%$ \\
\hline $\begin{array}{l}\text { Average \% of forestry base income in the paper and } \\
\text { allied sector (1991) }\end{array}$ & $43.3 \%$ & $42.8 \%$ & $30.7 \%$ & $36.3 \%$ & $37.7 \%$ \\
\hline Average earned income in forestry jobs per employee (1981) & $\$ 16826$ & $\$ 17773$ & $\$ 19060$ & $\$ 17010$ & $\$ 17564$ \\
\hline Average earned income in forestry jobs per employee (1991) & $\$ 32242$ & $\$ 31015$ & $\$ 31535$ & $\$ 28865$ & $\$ 31101$ \\
\hline$\%$ change in average income in forestry jobs per employee & $91.6 \%$ & $74.5 \%$ & $65.5 \%$ & $69.7 \%$ & $77.1 \%$ \\
\hline Average income in total industry jobs per employee (1981) & $\$ 12963$ & $\$ 14134$ & $\$ 14816$ & $\$ 13083$ & $\$ 13577$ \\
\hline Average income in total industry jobs per employee (1991) & $\$ 22610$ & $\$ 21875$ & $\$ 22861$ & $\$ 21825$ & $\$ 22456$ \\
\hline$\%$ change in average income per employee in total industry & $74.4 \%$ & $54.8 \%$ & $54.3 \%$ & $66.8 \%$ & $65.4 \%$ \\
\hline Average real \% change in total forest base income & $31.7 \%$ & $5.9 \%$ & $-28.7 \%$ & $-22.0 \%$ & $-1.2 \%$ \\
\hline Average real $\%$ change in total community base income & $39.7 \%$ & $-9.0 \%$ & $-15.0 \%$ & $18.8 \%$ & $16.6 \%$ \\
\hline
\end{tabular}

\section{Distinguishing Features of FRCs in Various Performance Classes}

The results in the previous section focus on the economic performance of FRCs nationally and regionally. This section considers distinguishing features and characteristics of the FRCs in each of the four quadrants. The purpose of this section is to determine if there are characteristics which are "related" to the economic performance of FRCs. It should be noted that the community characteristics described in this section are not necessarily determining factors of economic performance. The characteristics may be symptomatic of a range of other community specific factors and attributes that affect performance. Without detailed community level data and information it is not possible to determine the cause-effect relationship between community characteristics and performance. The following discussion focuses on four features of FRCs which may be related to community performance; average population, average income per employee, average degree of reliance on the forest sector, and average contribution of the paper and allied sector to total forest sector base income in FRCs.

\section{Size of community}

At the national level, larger FRCs performed better than small FRCs (note + the sample excluded CSDs with populations less than 1000 persons). Table 5 shows that the average population of FRCs in Quadrants 1 and 4 (i.e., growth FRCs) was 4708 and 6920 respectively. The average population in Quadrants 2 and 3 (decline FRCs) was 3269 and 4296.

Table 6 shows the average population of FRCs in each quadrant on a regional basis. The average size of B.C. and Ontario FRCs in 1981 was significantly higher than other regions: 7809 and 6745 respectively. The high average population of Ontario FRCs was primarily the result of the high average population of Quadrant 4 FRCs (20 679). This quadrant, in fact, included the City of Thunder Bay (1981 pop. = 112486 ) and its surrounding rural area (1981 pop. $=8053)$. The average size of B.C. FRCs was higher than the national average in all quadrants. Generally, B.C.'s FRCs are larger than in other areas; however, there were some particularly large FRCs within the sample. Quadrant 4 FRCs in B.C. for example included Nanaimo (1981 pop. $=47$ 069), and Terrace (1981 pop. $=10914)$.

\begin{tabular}{lccccc}
\hline \multicolumn{6}{l}{ Table 6. Average 1981 population by region and quadrant } \\
\hline & $\begin{array}{c}\text { Quadrant } \\
\text { 1 }\end{array}$ & $\begin{array}{c}\text { Quadrant } \\
\mathbf{2}\end{array}$ & $\begin{array}{c}\text { Quadrant } \\
\mathbf{3}\end{array}$ & $\begin{array}{c}\text { Quadrant } \\
\mathbf{4}\end{array}$ & Total \\
\hline Atlantic & 2156 & - & 2845 & 3983 & 2812 \\
Quebec & 2813 & 1654 & 3722 & 3663 & 3272 \\
Ontario & 3118 & 1155 & 3945 & 20679 & 6745 \\
Prairies & 4716 & 6390 & 2459 & 1890 & 3584 \\
B.C. & 10109 & 7104 & 5323 & 8332 & 7809 \\
All 222 & & & & & \\
communities & 4708 & 3269 & 4296 & 6920 & 5134 \\
\hline
\end{tabular}

Quadrant 1 FRCs in B.C. included Prince George (1981 pop. $=67559$ ) and Mission (1981 pop. $=20056$ ). The average population of FRCs in all other regions and all quadrants was lower than the national average with the exception of Quadrants 1 and 2 FRCs in the prairies (which are close to the national average) and Quadrant 4 FRCs in Ontario.

The national finding that large FRCs performed better than small FRCs does not consistently apply at the regional level. Quadrant 3 FRCs had higher population averages than Quadrant 1 FRCs in Atlantic Canada, Quebec, and Ontario. Thus, the finding at the national level that large FRCs performed better than small FRCs probably reflects the large number and higher average populations of B.C. FRCs. There is no consistent or apparent relationship between size of FRCs and performance in the other regions.

There is, however, one consistent pattern between regions. In each of the eastern regions (Atlantic, Quebec, Ontario), the average population in Quadrants 1 and 2 (i.e., forest base income growth) is lower than the average population in Quadrants 3 and 4 (forest income decline). The opposite was the case in western FRCs where the average population is generally higher in Quadrants 1 and 2 than Quadrants 3 and 4 (with the exception of B.C.'s Quadrant 4 FRCs). Forest industry growth in FRCs was more closely associated with smaller FRCs in eastern Canada and with larger FRCs in western Canada.

\section{Income}

Another variable of interest is average income per employee (or labour force participant). Table 7 shows that average employment income (1981) was lower in growth FRCs 
Table 7. Average earned income (\$ nominal) per labour force participant: 1981 and 1991

\begin{tabular}{|c|c|c|c|c|c|c|c|c|c|c|}
\hline & \multicolumn{2}{|c|}{$\begin{array}{c}\text { Quadrant } \\
1\end{array}$} & \multicolumn{2}{|c|}{$\begin{array}{c}\text { Quadrant } \\
2\end{array}$} & \multicolumn{2}{|c|}{$\begin{array}{c}\text { Quadrant } \\
3\end{array}$} & \multicolumn{2}{|c|}{$\begin{array}{c}\text { Quadrant } \\
4\end{array}$} & \multicolumn{2}{|c|}{ Total } \\
\hline & 1981 & 1991 & 1981 & 1991 & 1981 & 1991 & 1981 & 1991 & 1981 & 1991 \\
\hline Atlantic & 10460 & 18981 & - & - & 11847 & 17654 & 11778 & 19334 & 11010 & 18981 \\
\hline Quebec & 12989 & 22524 & 12935 & 20911 & 13218 & 20270 & 12238 & 20495 & 12804 & 21204 \\
\hline Ontario & 13071 & 23964 & 12951 & 18167 & 15309 & 26006 & 14204 & 25200 & 14250 & 24924 \\
\hline Prairies & 13945 & 21438 & 15780 & 23352 & 15104 & 21305 & 10363 & 18908 & 14192 & 21293 \\
\hline B.C. & 15505 & 26000 & 17267 & 26995 & 15980 & 23600 & 15229 & 24798 & 15654 & 24814 \\
\hline All 222 communities & 12963 & 22610 & 14134 & 21875 & 14816 & 22861 & 13083 & 21825 & 13577 & 22456 \\
\hline
\end{tabular}

(Quadrants 1 and 4) than in Quadrant 3 FRCs. Also, there was some equalization in income per employee between growth FRCs and decline FRCs over the period. Average income per employee increased between 1981 and 1991 by $74 \%$ and $67 \%$ in FRCs in Quadrants 1 and 4 . Average income per employee increased by 54\% in Quadrant 3 FRCs between 1981 and 1991.

These findings are of significance for two reasons. First, significant differences in income between CSDs suggest the presence of a number of geographically distinct labour markets within each region. Second, it suggests that the relationships between economic performance, investment, and average income is complex and that lower relative average income may not be an entirely bad thing from the point of view of sustainable communities. These issues are discussed in more detail in the "Analysis" section.

\section{Degree of reliance on the forest sector}

There was considerable regional variation in the degree of forest sector reliance within various performance classes (Table 4). In Atlantic Canada and Quebec, on average, FRCs with a relatively high degrees of forest reliance in 1981 performed better than FRCs with a lower degree of forest reliance. However, the degree of forest reliance declined between 1981 and 1991 (with the exception of Quadrant 2 in Quebec). This suggests that growth of non-forest base income in heavily forest-reliant CSDs was a contributing factor to the positive performance of these FRCs. Quadrant 3 FRCs in Ontario, the prairie region, and B.C. had the highest average degree of reliance on the forest sector of all quadrants in $1981(82.4 \%$, $80.9 \%$, and $75.4 \%$ ). Table 1 shows that on average these FRCs also suffered more significant declines in their economic base over the ten-year period $(13.1 \%, 21.8 \%$, and $17.4 \%)$ than FRCs in other quadrants.

\section{Forest industry structure}

The forest products sector is defined as logging, forestry services, wood industries, and the paper and allied sector. Total forest base income is the sum of wages and salaries paid by these sectors in the FRC. Tables 5 and 8 show the contribution of the paper and allied sector to total forest base income in FRCs nationally and by region. This indicator provides a rough measure of the structure of the forest industry within FRCs in the quadrants. With the exception of Atlantic Canada, the majority of forest base income in FRCs is provided by logging, forestry services and wood industries ${ }^{12}$. This was particularly true in Quadrant 3 FRCs where on average $70.1 \%$ of the 1981 total forest base income was accounted for by these industries. Forty nine percent of the 1981 forest base income in Quadrant
1 FRCs was provided by logging, forestry services and wood industries.

The contribution of logging, forestry services and wood industries was especially pronounced in B.C. FRCs. On average, income from these industries accounted for $85 \%$ of total forest industry base income (Table 8). The paper and allied industry contributed $15 \%$ of total forest base income ${ }^{13}$. B.C. FRCs that declined (Quadrants 2 and 3), were particularly logging and wood industry-oriented. On average, $90 \%$ of the total forestry base income in Quadrant 3 FRCs was provided by logging, forestry services and wood industries.

\section{Analysis}

The results and findings described in the previous sections point to a number of general conclusions regarding forest-reliant communities. First, there appears to be some relationship or correlation between low average income and positive economic performance in forest-reliant communities. Second, the condition of "forest reliance" is not necessarily a long term condition in many communities. Third, there are interregional differences in the propensity to form forest-reliant communities. Fourth, variations in performance within and between regions is the result of the considerable diversity in circumstances between individual forest-reliant communities. Further discussion of these four conclusions is provided in this section.

\section{Income differentials between FRCs}

Evidence of income differentials between FRCs within regions lead to two fundamental questions. First, what are the reasons for income differentials? Second, what is the significance of income differentials with respect to community sustainability? Gera and Grenier (1994) describe a number of factors that may contribute to inter-industry wage differentials. Some of these factors include: a) differences in working conditions (shift work, risk of injury, health hazards, full-time / part-time), b) differences in human resource characteristics (age, experience, gender, education level), c) differences in firm size, d) labour supply-demand shocks and labour immobility, e) inherent differences in worker productivity, $\mathrm{f}$ ) institutional effects (contractual arrangements, unionization) and, g) efficiency wages (i.e., willingness of select firms to pay high wages in order to

\footnotetext{
${ }^{12}$ The contribution of logging, forestry services, and wood industries is 100 minus the percent contribution by paper and allied industries.

${ }^{13}$ Wages paid to production and related workers by the B.C. forest industry in 1981 were logging $-\$ 421$ million (24\% of total), wood industries $-\$ 961$ million ( $54 \%$ of total), and paper and allied $-\$ 394$ million ( $22 \%$ of total) (Statistics Canada 1981).
} 
Table 8. Average percentage of forestry base income in the paper and allied industry: 1981 and 1991

\begin{tabular}{|c|c|c|c|c|c|c|c|c|c|c|}
\hline & \multicolumn{2}{|c|}{$\begin{array}{c}\text { Quadrant } \\
1\end{array}$} & \multicolumn{2}{|c|}{$\begin{array}{c}\text { Quadrant } \\
2\end{array}$} & \multicolumn{2}{|c|}{$\begin{array}{c}\text { Quadrant } \\
3\end{array}$} & \multicolumn{2}{|c|}{$\begin{array}{c}\text { Quadrant } \\
4\end{array}$} & \multicolumn{2}{|c|}{ Total } \\
\hline & 1981 & 1991 & 1981 & 1991 & 1981 & 1991 & 1981 & 1991 & 1981 & 1991 \\
\hline Atlantic & 44 & 50.2 & - & - & 54.1 & 56.7 & 50.4 & 51.2 & 50.4 & 51.1 \\
\hline Quebec & 52.3 & 53 & 59 & 59.7 & 36.6 & 37.5 & 39.7 & 37.1 & 44.5 & 44.1 \\
\hline Ontario & 44.6 & 42.8 & na & na & 47.8 & 46.7 & 51.7 & 59.6 & 46.1 & 46.5 \\
\hline Prairies & 67.1 & 74.7 & 71.1 & 71.1 & 33.3 & 33.1 & na & na & 43.8 & 45.7 \\
\hline B.C. & 22.6 & 24.1 & 3.2 & 6.6 & 10.2 & 12.1 & 13.1 & 11.9 & 15.4 & 16.5 \\
\hline All 222 communities & 40.9 & 43.3 & 41.9 & 42.8 & 29.9 & 30.7 & 39.1 & 36.3 & 37.7 & 37.7 \\
\hline
\end{tabular}

minimize turnover costs, provision of wage premiums to attract higher quality workers, internal equity, social conventions, employee loyalty). Similar factors may also contribute to the inter-regional differences in income observed in this study. However, verification of the specific factors contributing to income differentials between FRCs requires further study.

Differences in average income between FRCs within regions and the apparent relationship between low average income and positive performance have a number of implications. First, this evidence suggests that there is a series of geographically distinct labour markets each with characteristics that serve to delineate or segregate these markets. This may mean that firms (especially larger firms) are in a monopsonistic position relative to the determination of labour wages in some FRCs. Firms in CSDs with low initial average income have a temporary comparative advantage which in turn attracts new investment into the CSD, thereby increasing the demand for labour and labour wages. Second, low initial average income is related to positive economic base income growth. As mentioned in the previous point, the initial comparative advantage of firms in low income CSDs provides an incentive for new investment (ceteris peribus). Thus, low average income operates as a positive factor relative to the sustainability of communities.

\section{Permanency of forest reliance in FRCs}

Between 1981 and 1991, a number of CSDs (29) that were non-forest-reliant in 1981 became reliant in 1991 (Fig. 1). Also, a number of the 1981 FRCs (77) either lost their forest reliance between 1981 and 1991 or dropped below the 1000 population level. As discussed in the results section, for those CSDs that were reliant on the forest products sector in both 1981 and 1991, there was a general trend for FRCs to become less forest-reliant + primarily due to growth in non-forest base sectors. This suggests that forest reliance is, in many cases, only a temporary phenomena and not a long term feature or economic characteristic of some communities. The development of some of these communities is represented by a small community attracting a major forest industry facility thereby simultaneously growing and becoming forest-reliant. Subsequently, however, the community begins to supply a wide variety of goods and services outside the CSD, thereby becoming more diverse and less forest-reliant. Eventually, the community becomes diversified and non-forest-reliant. This is an example of just one of a multitude of successional trajectories that a particular community might follow. However, the example and the results illustrate the fact that evolution in the economic structure of forest-reliant communities over time is part of an ongoing and natural process of dynamic change involving constant and continual redefinition of the linkages, interactions and inter-relationships between the economic system within a particular community and higher and lower order economic systems.

\section{Propensity to form forest-reliant communities}

The results section notes some differences in the number of FRCs between regions, in the performance of FRCs between regions, and in the characteristics of FRCs between regions. For example, although the volume of primary forest production in the prairie region in 1981 was roughly equivalent to the volume of primary forest production in Atlantic Canada in 1981, there were 46 sample FRCs in Atlantic Canada and only 7 in the prairie region. This section introduces various hypotheses about the seemingly stronger propensity for formation of forest-reliant communities in the Atlantic region.

Part of the reason for the stronger propensity for establishment of FRCs in Atlantic Canada may be attributable to differences in the historical context for forest industry development in the two regions. Robson (1995) suggests that there has been a number of defining periods relative to patterns of development in resource-based communities in Canada. These periods include the "holistic period" which roughly coincides with the period 1900 to 1945 , the "comprehensive period" which roughly corresponds to the period from the 50 s to the 80 s and the "decline management period" which describes contemporary location patterns for forest industry investment relative to communities. Prior to the holistic period, forestry towns were largely company towns (or in some cases large temporary camps). During the holistic era, community planning concepts began to be implemented so that a more structured and organized approach was increasingly being used for community development. However, in many cases, the day-to-day management of community affairs was largely retained by the large companies. The "comprehensive era" was a period characterized by rapid growth in resource exploitation and in the number of single industry, forest-dependent communities. Control of community affairs was transferred from the company to local residents. A conscious effort was made to change the image of towns from temporary sites to a greater focus on "permanency, stability and sociability."

According to Robson (1995), the contemporary approach to community development (termed the decline management era) encompasses a trend away from the creation of new mill towns to the expansion of existing town sites. This "growth-centre" approach is in response to a) changing global economic circumstances, b) the increasingly competitive nature of the industry and c) the need for providing a greater range 


\begin{tabular}{|c|c|c|c|c|}
\hline \multirow[b]{2}{*}{ Province/region } & \multicolumn{2}{|c|}{ \# of pulp and paper mills } & \multicolumn{2}{|c|}{ Sawmill employment } \\
\hline & 1950 & 1980 & 1950 & 1980 \\
\hline Newfoundland & 3 & 2 & 947 & 94 \\
\hline PEI & - & - & 154 & 28 \\
\hline Nova Scotia & 4 & 5 & 3111 & 1046 \\
\hline New Brunswick & 7 & 11 & 3216 & 2254 \\
\hline Atlantic & 14 & 18 & 7428 & 3422 \\
\hline Manitoba & 2 & 4 & 574 & 396 \\
\hline Saskatchewan & - & 1 & 733 & 415 \\
\hline Alberta & - & 5 & 2051 & 2057 \\
\hline Prairie region & 2 & 10 & 3358 & 2868 \\
\hline
\end{tabular}

Sources: Statistics Canada - Canadian Forestry Statistics: 1950; Canadian Forestry Statistics: 1980; The Pulp and Paper Industry: 1950; Pulp and Paper Mills: 1981.

Note: Declines in sawmill industry employment between 1950 and 1980 may be partly due to reduced coverage in industrial surveys.

of urban-like services to rural residents. The transition between these eras has probably been gradual and incremental. Currently, the forest economy appears to be in the midst of a transition from the "comprehensive era" to the "decline management era." Thus, depending on historical context, remnants of previous patterns may be apparent in some regions at the same time as evidence of new patterns are more evident in other regions.

The Atlantic Canada forest industry was actually well established prior to WW II. By 1950, there were a total of 14 pulp and paper mills in the region compared to two in the prairie region (Table 9). Total employment in the Atlantic Canada lumber industry was over 7000 compared to around 3000 in the prairies. If forest industry development immediately before and after 1950 followed Robson's generalized model for community development during the "comprehensive era," then forest industry development probably resulted in the formation of new towns and the significant expansion and revitalization of existing small towns resulting in a general increase in the number of forest-reliant communities. The period following WW II was a period of significant consolidation, expansion and restructuring in the forest industry in Atlantic Canada. For example, the Irving family purchased large areas of forested lands from railway companies a precursor to the establishment of one of the world's major forest industry companies ${ }^{14}$. Although lumber industry employment declined, the number of pulp and paper mills in the region increased from 14 to 18 . As noted in Tables 6 and 8, 1981 FRCs in Atlantic Canada were relatively small (compared to other regions) and were more dependent on the paper and allied industry suggesting that forest industry expansion (primarily focussing on paper and allied industry expansion and related logging activities) between 1950 and 1980 resulted in the creation of new forest-reliant communities or the evolution of existing communities into forestreliant communities (note - the 18 pulp and paper mills may be supporting or contributing to more than 18 CSDs). The large number of FRCs in Atlantic Canada in 1981 reflects a pattern of development which is consistent with general resource-based community development pattern described by Robson as the comprehensive era of community development. Moreover, to some degree aspects of the comprehensive era development patterns are also apparent in the 1981 to 1991 period. For example, Quadrant 1 FRCs (i.e., FRCs with forest income growth

${ }^{14}$ Personal communication, Bill Anderson, Forest Sector Advisory Council
Secretariat, Natural Resources Canada, Canadian Forest Service, Ottawa. 1998. and community growth) are smaller (by population) than FRCs in other quadrants, indicating a higher propensity for smaller FRCs to attract new forest industry investment than larger FRCs. At the same time, Quadrant 4 FRCs are relatively large. This pattern suggests that forest investment leads to the establishment and initial growth of many FRCs followed by growth and expansion of other industries as the local forest industry matures.

Significant development of the forest products industry in the prairie region is a much more recent phenomena compared to Atlantic Canada. In 1950 there were two pulp and paper mills in the region and only one was a major primary producer relying on harvested roundwood (the mechanical newsprint mill at Pine Falls, Manitoba). A number of pulp and paper mills were constructed between 1950 and 1980, but in almost every case the mills were located in relatively large and well established communities (eg. The Pas, Manitoba; Prince Albert, Saskatchewan; Hinton, Alberta; and Grande Prairie, Alberta). Thus, whereas the general trend in the development of communities in Atlantic Canada can be characterised by forest industry investment leading the early establishment and/or growth of communities followed by new industry and general diversification, community development in the prairie region is more characterized by forest industry investment occurring in already large and established communities. In Atlantic Canada non-forest-based industry is diversifying existing forest-reliant communities, while in the prairie region the forest industry is contributing to the diversification of existing communities (which may have been previously dependent on other non-forest base sectors such as agriculture, mining, services, oil and gas, etc).

One implication of these findings is that the phenomenon of forest-reliant communities may be becoming increasingly less prevalent over time. As noted in the results section, FRCs that are growing are also, in most cases, becoming more diversified (with the exception of Ontario Quadrant 1 FRCs). Although 29 CSDs became forest-reliant between 1981 and 1991, 77 FRCs lost their forest reliance. The high forest reliance index of decline FRCs (Quadrant 3) in Ontario, the Prairies, and B.C. may be an indication that these FRCs lack any significant comparative advantage in alternative economic base sectors other than the forest industry. As the forest industry capital matures in these heavily forest-reliant FRCs, they may face steady or drastic contraction unless they are able to attract new forestry investment or other nonforest-based industries. 
It is important to note that the evolution in patterns of development is a long-term process. Although the phenomenon of forest-reliant communities is becoming less prevalent over time, there still exists a significant population who continue to reside in these communities. Thus, these communities continue to be have present and future policy relevance in terms of the social conditions and economic challenges and opportunities which face residents of FRCs.

\section{Diversity of circumstances in FRCs}

One of the objectives of this study is to evaluate if there were systematic differences between successful and contracting FRCs in terms of population, average income, degree of forest reliance, and forest industry composition. Some general relationships are evident at the aggregate national level, but there is significant variation in the individual CSD observations. Also, there are significant variations in patterns between regions. For example, on average, Quadrant 1 communities are smaller than Quadrant 3 communities in Atlantic Canada, Quebec, and Ontario, but larger in the prairie region and B.C. The average degree of forest reliance is higher in Quadrant 4 communities than Quadrant 3 communities in Atlantic Canada and Quebec, but lower in Ontario, the prairies and B.C. This apparent randomness suggests that the circumstances and development prospects of individual FRCs are diverse. The remainder of this section discusses possible reasons for the diversity of circumstances in individual FRCs.

The Canadian Rural Restructuring Foundation (CRRF) suggests that "there is not one force or a single mode of adjustment, but a series of rationalizations and opportunities which produce different responses to globalization in different rural milieu. The impact is one of fragmentation, differentiation, and complexity in a climate of uncertainty." 15 The lack of clear and obvious patterns and the high degree of variability of the characteristics of FRCs within particular performance classes is consistent with the CRRF statement. As mentioned in the results section, variation in the characteristics and performance of FRCs is apparent both within and between performance classes and regions. Such variation may be attributable to both differences in local factors and differences in exposure to, and capacity to adapt to, external forces originating from both forest sector markets and higher order economies.

Some interrelated local level community attributes which influence industrial comparative advantage, profitability and community economic performance include location relative to markets and distribution systems, resource availability, structural linkages to higher and lower-order economies, size and structure of the non-basic sector, strength of local institutions and social structures, skill level and productivity of the labour force, community infrastructure and amenities, entrepreneurship of local residents, profitability of locally employed technologies, and size of local firms and mills relative to rivals and competitors. Apedaile (1992) identifies other features that affect behaviours within economic systems including "memory of historical events and emotions, the technologies and know-how, the learning processes at work for the system and the vision of the future held collectively within the

\footnotetext{
${ }^{15}$ From "Understanding the new rural economy: choices and options." A CRRF research proposal for rural Canadians - presented to the Interdepartmental Committee on Rural and Remote - December, 1996.
}

system." These are a few endogenous features that influence the capacity of communities to respond and adapt to external change, to attract investment and to develop and grow over time. The mix of these attributes varies from location to location.

The economic performance of communities also depends on decisions and choices by firms, households, and governments both within and outside the community. These decisions and choices are determined through an ongoing process of weighing the various costs and benefits of choices, and adopting a course of action that maximises the net benefits to the individual decision-maker (e.g., profits, personal satisfaction, income and wealth, social welfare, environmental quality, utility, etc.). Local community attributes have a strong influence on decisions made by local and external decision-makers. They may influence the choice of individuals to stay in the community, the decision of a local firm to reinvest its profits in the community, the decision of a corporation to inject capital into the community from outside, etc. However, decisions by local and external decision-makers can also be significantly influenced by external trends and forces such as globalization, industrial restructuring, maturing markets, emerging markets, exchange rates, regulatory changes, institutional changes and changes in tastes, values and preferences of society. Again, the influence of these external forces on economic performance and circumstances will vary from community to community.

Ultimately, it is the interactions between firms, households, and governments within the community and firms, households and governments outside the community that determine the development paths of particular communities. These interactions are conditioned by the local circumstances and attributes of particular communities as well as by institutional structures within and external to the community (Kraybill and Weber 1995). The diversity of internal and external factors facing individual communities and the complexity of the interactions between these factors contributes to a compelling diversity of circumstances and responses, even within communities with a degree of commonality in terms of their dominant industrial bases (such as FRCs).

\section{Applications}

The results of this study have two practical applications. First, they provide an opportunity to preliminarily identify and characterize FRCs that underwent moderate to severe contraction between 1981 and 1991. Second, they provide overall indicators of the economic sustainability of individual communities.

\section{Contracting communities}

Some forest-reliant CSDs may not be economically sustainable in the long run. For any number of reasons they are undergoing moderate and, in some cases, significant contraction in economic base income ${ }^{16}$. Two general policy directions to reduce the negative social impacts of economic contraction in communities dominated by a single sector such as the forest

\footnotetext{
${ }^{16}$ Due to the fact that the economic base is measured in terms of earned income, contraction in the economic base may reflect reduced production within the community or technological change effects (i.e., the substitution of labour for capital leading to reduced jobs). The net effect of technological change on the economic base will depend on the number of jobs lost, and the average income of employees using the new technology. The economic base may show some reductions if old technology jobs times old technology incomes are less than new technology jobs times new technology income.
} 
industry might be: a) to encourage orderly transitions in communities undergoing moderate contraction, and b) to identify communities that are in the midst of significant economic contraction and attempt to minimize the negative social consequences.

Of the 222 FRCs in the sample, the economic base in the majority (150 FRCs in Quadrants 1 and 4) grew between 1981 and 1991. Their positive economic performance was the result of positive growth in the dominant industry (i.e., the forest products industry), or positive growth in other non-forest export base industries, or some combination of the two. The positive economic performance of these FRCs during the period suggests that the necessary economic fundamentals required to support economic development and diversification were present.

The 66 FRCs in Quadrant 3 are FRCs where both forest sector base income and the total economic base of the FRC declined between 1981 and 1991. Forest sector base income declined at an average annual rate of $2.9 \%$ (Table 5) per year and community base income declined an average annual rate of $1.5 \%$ per year. Here again, contraction could be due to either production declines or technological change (see footnote 17). Some possible consequences of contraction in base income within these FRCs could be downward pressure on the municipal tax base and property values, decay in community infrastructure, increased reliance on social and employment transfer payments, increased pressure to relocate, and higher levels of social instability within these FRCs exemplified by increased breakdown of family units, increased crime, substance abuse, lower degrees of social interaction, and breakdown of community institutions.

One practical application of this study is that the analysis provides an opportunity to identify FRCs that underwent moderate to severe contraction. Prevention or mitigation of the social problems described in the previous paragraph are the primary reasons for defining specific policies relative to resource-dependent communities. Targeted policies require some understanding of which communities are at risk of economic contraction. Measures of the historical economic performance of communities can help to identify which communities require further analysis, monitoring or specific actions.

In order to preliminarily differentiate FRCs with moderate contraction from FRCs with significant contraction, Quadrant 3 FRCs are sub-divided into two groups. FRCs where the economic base declined between 0 and $25 \%$ between 1981 and 1991 are identified as FRCs with moderate contraction. There were 53 FRCs in this category. Appendix 1 lists these FRCs and provides information on province, CSD type, and percent decline in the total economic base between 1981 and 1991. FRCs where the rate of contraction exceeded $25 \%$ between 1981 and 1991 are defined as FRCs with severe contraction. There were 13 FRCs in this category. Appendix 2 lists these FRCs.

Some cautionary notes about the list of communities in Appendices 1 and 2 are warranted. First, the sample was limited to CSDs where the boundary did not change between 1981 and 1991. There may be other CSDs where base income declined but because of changes in boundaries, the CSD was excluded from the sample. Second, the sample does not include small communities (i.e., CSDs with populations less than 1000 persons). Third, in some cases FRCs that declined significantly between 1981 and 1991 may have subsequently rebounded as a result of new investment and increased production. In some cases, the firms in FRCs that grew between 1981 and 1991 may have failed after 1991. Fourth, the economic base model is restricted to measuring injections into a local economy which are derived from the export of goods and services. However, the economic base model does not reflect or capture differences in the ability to retain and re-circulate income within the community ${ }^{17}$. Communities with strong performance in their export base earnings but with high rates of income leakage may not be as successful as communities with lower base income growth but parallel reductions in their rate of income loss through leakages out of the community (Power 1995). Finally, the results may to some extent reflect biases resulting from modelling assumptions and/or errors in census data.

The approach and results provided in this section outline a way of providing preliminary information for the purpose of assessing and identifying medium-sized and larger FRCs suffering moderate to major declines in economic base income. More information on the specific circumstances of the identified FRCs should be obtained to verify and validate the nature and extent of restructuring and transition issues in these CSDs.

\section{Indicators of community sustainability}

The following is quoted from the Canadian Council of Forest Ministers (CCFM) booklet, Criteria and Indicators of Sustainable Forest Management in Canada +1997 Progress to Date:

"Within or adjacent to forested regions across Canada are hundreds of communities that rely on the forest sector. Indicators related to the sustainability of these communities contribute to an overall understanding of the sustainable management of our forests. For example, if these communities continue to be economically, culturally, and spiritually sustained by their local forests, the forests are likely being managed on a sustainable basis. However, if the health and productivity of the forests decline through natural events (e.g., fires or insect outbreaks) or human impacts (e.g., pollution or unsustainable harvest rates), the communities' viability may be compromised." (CCFM 1997)

The CCFM report indicates that there were 337 Canadian communities classified as heavily forest-reliant and an additional 1294 communities that were moderately reliant in 1991. Although it is important to know the magnitude and distribution of forest-reliant communities, a static snapshot provides little information on the health, resiliency and outlook for these communities. The results of this study, extend the results in the CCFM report by considering the economic performance of FRCs over a ten-year period. The performance quadrant approach described in this study provides a basis for assessing the extent to which the economies of FRCs are sustained over time. It also provides an opportunity to stratify forest-reliant communities according to their health and resiliency as measured by their economic performance. Although, FRCs generally performed well, some communities suffered significant

\footnotetext{
$\overline{{ }^{17} \text { There are a number of sources of income leakages from communities, includ- }}$ ing payments for imports, income transfers out of the community, and/or expenditures by local residents outside the community.
} 
declines in economic base income. The question of whether these declines are attributable to unsustainable forest management or other factors requires further investigation.

\section{Summary and Areas of Future Research}

Widespread negative effects of economic restructuring were not observed in FRCs between 1981 and 1991. Nationally, FRCs had positive economic performance over the period. A significant proportion of the growth of (and in some cases avoidance of significant collapse in) FRCs was, however, attributable to growth in non-forest sectors. There was a general tendency for FRCs to become less reliant over the ten-year period due to some combination of declining production in the forest industry in some communities, technological change and to growth in non-forest economic base sectors.

Although in aggregate FRCs exhibited positive economic growth over the period, there were 66 FRCs where both total community base income and forest base income declined. In some cases (13 FRCs) the rate of decline in economic base income was significant (i.e., greater than 25\%). Contraction of base income in these FRCs may be the result of forest industry contraction, contraction of other economic base sectors, technological change and labour displacement, or some combination of the above.

This study has not attempted to describe why base income in FRCs declined and, therefore, it can not suggest specific policy options relative to the role, design, or practicality of interventions in declining communities. The specific reasons for decline in the economic base of these communities are complex and multi-dimensional and vary from community to community. However, the results are still relevant to policymakers. Policy responses to the unique and evolving challenges and needs of rural residents and residents of forest-based communities are becoming more common. The design, implementation, and evaluation of policy with community-related objectives requires an understanding of the location of communities with special needs, their structure and their historical performance.

The qualitative analysis provided in this study points to a number of questions which may merit further study. The first is the need to study the dynamics of change in forest-reliant communities in more depth and to develop a stronger understanding of the various determinants of economic performance at the community level. A second area of research would be to undertake analysis of variance of the data used in this study for the purpose of evaluating the statistical significance of differences in the various quadrant averages and to interpret these findings. A third area of possible research would be to update the measure of economic performance of the sample of 222 1981 FRCs using the recently released 1996 Census data. A fourth research area would be to investigate in more detail the interrelationships between income, economic performance and community sustainability. Finally, a fifth research direction is to investigate how the expenditure patterns of local residents affect the measure of economic performance and the criteria for identifying forest-reliant communities.

\section{Acknowledgments}

The authors wish to thank Dr. W. White and Mr. D. McFarlane for their technical comments and Mr. J. Olivier for preparing the graphs.

\section{References}

Apedaile, L.P. 1992. The economics of rural-urban integration: a synthesis of policy issues. In R. Bollman (ed.). Rural and small towns in Canada. Thompson Education Publishing Inc.

Berck, T.M., D. Burton, G. Goldman and J. Geoghegan. 1992. Instability in forestry and forestry communities. In P.N. Nemetz (ed.). Emerging issues in forest policy. UBC Press, Vancouver, B.C.

Brown, S.J., N.E. Coulson and R.F. Engle. 1992. On the determination of regional base and regional base multipliers. Regional science and urban economics. 22(4): 619-635.

Byron, R.N. 1978. Community stability and forest policy in British Columbia. Can. J. For. Res. 8: 61-66.

Canadian Council of Forest Ministers. 1997. Criteria and indicators of sustainable forest management in Canada - 1997 Progress to date. Ottawa, Ontario.

Canadian Forest Service. 1996. Selected forestry Statistics Canada 1995. Industry, Economics and Programs Branch, Canadian Forest Service, Ottawa, Ont. Inf. Rep. E-X-48.

Clemenson, H. 1992. Are single industry towns diversifying? An examination of fishing, forestry and mining towns. In R. Bollman (ed.). Rural and small town Canada. Thompson Education Publishing Inc.

Fletcher, S., W. White, W. Phillips and L. Constantino. 1991. An economic analysis of Canadian prairie provinces forest dependent communities. Department of Rural Economy, Faculty of Agriculture and Forestry, University of Alberta, Edmonton, Alberta. Project report No. 91-05.

Gera, S. and G. Grenier. 1994. Inter-industry wage differentials and efficiency wages: some Canadian evidence. Canadian Journal of Economics 27(1): 81-100.

Horne, G. and C. Penner. 1992. British Columbia community employment dependencies: Final report. Prepared for the British Columbia Forest Resources Commission. Planning and Statistics Division, B.C. Ministry of Finance and Corporate Relations. Victoria, B.C. Kraybill, D.S. and B.A. Weber. 1995. Institutional change and economic development in rural America. Amer. J. Ag. Econ. 77: 1265-1270.

National Forestry Database Program. 1997. Compendium of Canadian Forestry Statistics 1996. Canadian Council of Forest Ministers. Ottawa, Ontario.

Power, T.M. 1995. The changing economic role of natural resources. In Proceedings of a conference on "International management of the North Cascades" The North Cascades National Parks and Conservation Association, Des Moines, Iowa.

Richardson, H.W. 1985. Input-output and economic base multipliers: looking backward and forward. Journal of Regional Science 25(4): 607-661.

Robson, R. 1995. Forest dependent communities in Canada: An interpretive overview and annotated bibliography. Natural Resources Canada, Canadian Forest Service, Industry, Economics and Programs Branch. Working Paper No. 39. Ottawa, Ontario.

Schallau, C., W. Maki and J. Beuter. 1969. Economic impact projections for alternative levels of timber production in the Douglasfir region. Annals of Regional Science 3(1): 96-106.

Statistics Canada. 1981. Canadian forestry statistics 1981. Ottawa, Ont. Cat. No. 25-202.

Statistics Canada. 1992. Census divisions and census subdivisions: Reference maps. Cat. No. 92-319. Ottawa, Ontario.

Statistics Canada. 1996. Canadian Economic Observer. Cat. No. 11210. Ottawa, Ontario.

Williamson, T.B. and S. Annamraju, S. 1996. Analysis of the contribution of the forest industry to the economic base of rural communities in Canada. Natural Resources Canada, Canadian Forest Service, Industry, Economics, and Programs Branch. Working Paper No. 43. Ottawa, Ontario. 
Appendix 1

Names and features of FRCs where forest sector base income declined and the economic base declined between 0 and $25 \%$ between 1981 and 1991 .

Note: There are 52 CSDs in the following list. The main text indicates that there are 53 CSDs where forest base income declined and total CSD base income declined between 0 and $25 \%$ between 1981 and 1991. A technical anomaly caused an erroneous result in one CSD and it was deleted from the list. However, there was insufficient time to recalculate all the values for the tables. Therefore, the text and tables in the main text have included this CSD in Quadrant 3 in Quebec.

\begin{tabular}{|c|c|c|c|c|c|c|}
\hline Province & $\begin{array}{l}\text { Name of CSD } \\
(1981)\end{array}$ & CSD type & $\begin{array}{l}\text { Population } \\
\text { (1981) }\end{array}$ & $\begin{array}{l}\% \text { of the } \\
\text { economic base } \\
\text { in the forest } \\
\text { products sector } \\
\text { (1981) }\end{array}$ & $\begin{array}{l}\% \text { of the forest } \\
\text { economic base } \\
\text { in the paper and } \\
\text { allied sector } \\
\text { (1981) }\end{array}$ & $\begin{array}{l}\% \text { change } \\
\text { in the } \\
\text { economic base }\end{array}$ \\
\hline Newfoundland & Botwood & Town & 4074 & 73.2 & 71.3 & -4.7 \\
\hline New Brunswick & $\begin{array}{l}\text { Rivière-verte } \\
\text { Eldon } \\
\text { Dalhousie }\end{array}$ & $\begin{array}{l}\text { Village } \\
\text { Parish } \\
\text { Town }\end{array}$ & $\begin{array}{l}1054 \\
1293 \\
4958\end{array}$ & $\begin{array}{l}52.6 \\
61.4 \\
87.9\end{array}$ & $\begin{array}{l}34.3 \\
11.5 \\
99.3\end{array}$ & $\begin{array}{l}-14.7 \\
-11.8 \\
-11.4\end{array}$ \\
\hline Quebec & $\begin{array}{l}\text { Petit-Saguenay } \\
\text { Ferme-Neuve } \\
\text { Grand'Mere } \\
\text { Donnacona } \\
\text { Sacre-Coeur-de-Jésus } \\
\text { Portneuf } \\
\text { Saint-Raymond } \\
\text { Saint-charles-de-Mandeville } \\
\text { Saint-Pamphile } \\
\text { Forestville } \\
\text { Chandler } \\
\text { Sainte-Aurelie } \\
\text { Mistassini }\end{array}$ & $\begin{array}{l}\text { Sans désignation } \\
\text { Village } \\
\text { Ville } \\
\text { Ville } \\
\text { Paroisse } \\
\text { Ville } \\
\text { Ville } \\
\text { Sans désignation } \\
\text { Ville } \\
\text { Ville } \\
\text { Ville } \\
\text { Sans désignation } \\
\text { Ville }\end{array}$ & $\begin{array}{rl}1 & 163 \\
2 & 266 \\
15 & 442 \\
5 & 731 \\
1 & 047 \\
1 & 333 \\
3 & 605 \\
1 & 392 \\
3428 \\
4271 \\
3946 \\
1045 \\
6682\end{array}$ & $\begin{array}{l}75.8 \\
77.5 \\
57.1 \\
88.8 \\
72.8 \\
56.3 \\
57.1 \\
50.3 \\
82.9 \\
58.3 \\
70.4 \\
73.7 \\
78.7\end{array}$ & $\begin{array}{c}0 \\
0 \\
95.2 \\
100 \\
100 \\
98.7 \\
26.9 \\
0 \\
0 \\
0 \\
98.5 \\
0 \\
24.9\end{array}$ & $\begin{array}{r}-24.6 \\
-21.8 \\
-14.5 \\
-12.8 \\
-12.1 \\
-11.3 \\
-11.1 \\
-4.5 \\
-3.8 \\
-3.7 \\
-2.7 \\
-1.2 \\
-0.7\end{array}$ \\
\hline Ontario & $\begin{array}{l}\text { Massey } \\
\text { Dryden } \\
\text { Longlac } \\
\text { Kapuskasing } \\
\text { White River } \\
\text { Owens, Williamson and Iding } \\
\text { Iroquois Falls } \\
\text { Fauquier } \\
\text { Barry's Bay } \\
\text { Terrace Bay } \\
\text { Geraldton } \\
\text { Fort Frances } \\
\text { Nipigon }\end{array}$ & $\begin{array}{l}\text { Town } \\
\text { Town } \\
\text { Town } \\
\text { Town } \\
\text { Township } \\
\text { Township } \\
\text { Town } \\
\text { Township } \\
\text { Village } \\
\text { Township } \\
\text { Town } \\
\text { Town } \\
\text { Township }\end{array}$ & $\begin{array}{r}1274 \\
6640 \\
2431 \\
12014 \\
1006 \\
1518 \\
6339 \\
1509 \\
1216 \\
2644 \\
2956 \\
8906 \\
2681\end{array}$ & $\begin{array}{l}54.9 \\
95.1 \\
98.1 \\
96.7 \\
85.3 \\
86.6 \\
89.3 \\
94.8 \\
51.6 \\
99.4 \\
85.2 \\
82.5 \\
81.7\end{array}$ & $\begin{array}{c}84.2 \\
71.8 \\
2.7 \\
58.1 \\
0 \\
23.8 \\
91 \\
76.3 \\
0 \\
99.7 \\
24.8 \\
77.4 \\
56.7\end{array}$ & $\begin{array}{l}-24.2 \\
-22 \\
-10.3 \\
-9.7 \\
-9 \\
-8.6 \\
-7.4 \\
-3.9 \\
-1.8 \\
-1.4 \\
-0.6 \\
-0.6 \\
-0.5\end{array}$ \\
\hline Manitoba & Alexander & $\begin{array}{l}\text { Local government } \\
\text { district }\end{array}$ & 2793 & 77 & 100 & -18.9 \\
\hline Saskatchewan & Hudson Bay No. 394 & Rural municipality & 2224 & 74.9 & 0 & -17.6 \\
\hline \multirow[t]{19}{*}{ British Columbia } & $\begin{array}{l}\text { Central Kootenay Sub. B } \\
\text { Columbia-Shuswap,Sub. C }\end{array}$ & $\begin{array}{l}\text { Subdivision of } \\
\text { regional district } \\
\text { Subdivision of }\end{array}$ & 12651 & 56.4 & 4.3 & $\begin{array}{l}-24.7 \\
-23\end{array}$ \\
\hline & 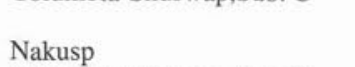 & $\begin{array}{l}\text { regional district } \\
\text { Village }\end{array}$ & 1495 & 71.8 & 0 & \\
\hline & Fraser-Fort George, Sub. B & $\begin{array}{l}\text { Subdivision of } \\
\text { regional district }\end{array}$ & 2428 & 71.2 & 0 & -21.5 \\
\hline & East Kootenay, Sub. A & $\begin{array}{l}\text { Subdivision of } \\
\text { regional district }\end{array}$ & 4449 & 58.5 & 0 & -16.8 \\
\hline & Central Coast, Sub. A & $\begin{array}{l}\text { Subdivision of } \\
\text { regional district }\end{array}$ & 1774 & 67.2 & 24.4 & -15.9 \\
\hline & Merritt & City & 6110 & 55.9 & 0 & -14.8 \\
\hline & Burns Lake & Village & 1777 & 81.1 & 0 & -14.2 \\
\hline & Ladysmith & Town & 4558 & 74.4 & 21.2 & -13 \\
\hline & Central Kootenay,Sub. A & $\begin{array}{l}\text { Subdivision of } \\
\text { regional district }\end{array}$ & 7618 & 68.8 & 23.8 & -12.3 \\
\hline & Port Alice & City ... & 1668 & 99.4 & 71.7 & -12.2 \\
\hline & Alberni-Clayoquot,Sub. A & $\begin{array}{l}\text { Subdivision of } \\
\text { regional district }\end{array}$ & 8984 & 93 & 23 & -12 \\
\hline & Port Alberni & City & 19892 & 97.1 & 31 & -10.2 \\
\hline & North Okanagan, Sub. A & $\begin{array}{l}\text { Subdivision of } \\
\text { regional district }\end{array}$ & 3277 & 62.4 & 0 & -8.2 \\
\hline & One Hundred Mile House & Village & 1925 & 81.7 & 0 & -6.1 \\
\hline & Bulkey-Nechako,Sub. A & $\begin{array}{l}\text { Subdivision of } \\
\text { regional district }\end{array}$ & 7841 & 72.3 & 0 & -5.8 \\
\hline & Fraser-Cheam, Sub. A & $\begin{array}{l}\text { Subdivision of } \\
\text { regional district }\end{array}$ & 3983 & 54.8 & 0 & -4.3 \\
\hline & Thompson-Nicola, Sub. A & $\begin{array}{l}\text { Subdivision of } \\
\text { regional district }\end{array}$ & 8400 & 84.5 & 0 & -3.1 \\
\hline & Fort St.James & Village & 2284 & 98.1 & 0 & -1.6 \\
\hline & Cumberland & Village & 1947 & 85.3 & 0 & -0.8 \\
\hline
\end{tabular}




\section{Appendix 2}

Names and features of FRCs that declined by more than $25 \%$ between 1981 and 1991 .

\begin{tabular}{|c|c|c|c|c|c|c|}
\hline Province & $\begin{array}{l}\text { Name of CSD } \\
(1981)\end{array}$ & CSD type & $\begin{array}{l}\text { Population } \\
\text { (1981) }\end{array}$ & $\begin{array}{l}\% \text { of the } \\
\text { economic base } \\
\text { in the forest } \\
\text { products sector }\end{array}$ & $\begin{array}{l}\% \text { of the forest } \\
\text { economic base } \\
\text { in the paper and } \\
\text { allied sector }\end{array}$ & $\begin{array}{l}\% \text { change } \\
\text { in the } \\
\text { economic base }\end{array}$ \\
\hline \multirow[t]{3}{*}{ Quebec } & Normetal & Sans désignation & 1393 & 50.5 & 39.5 & -32.9 \\
\hline & Senneterre & Ville & 4339 & 54 & Nil & -31.4 \\
\hline & Price & Village & 2273 & 55 & 12.5 & -30 \\
\hline \multirow{3}{*}{ Ontario } & Jaffray and Melick & Town & 3671 & 61.5 & 79 & -43.3 \\
\hline & $\begin{array}{l}\text { Cochrane, unorganized, } \\
\text { North part }\end{array}$ & Unorganized & 7059 & 72.1 & 18.9 & -39 \\
\hline & Eilber and Devitt & Township & 1254 & 82.9 & 0 & -26.6 \\
\hline Saskatchewan & HudsonBay & Town & 2361 & 91 & 0 & -28.9 \\
\hline \multirow[t]{6}{*}{$\mathrm{BC}$} & Lake Cowichan & Village & 2391 & 97.7 & 14.3 & -40.3 \\
\hline & Duncan & City & 4228 & 72.5 & 46.3 & -40.2 \\
\hline & Tahsis & Village & 1739 & 99.6 & 0 & -36.3 \\
\hline & $\begin{array}{l}\text { Mount Waddington } \\
\text {-Subd B }\end{array}$ & $\begin{array}{l}\text { Subdivision of } \\
\text { regional district }\end{array}$ & 2705 & 85.4 & 0 & -34.9 \\
\hline & $\begin{array}{l}\text { Skeena - Queen Charlotte } \\
\text { - Sub }\end{array}$ & $\begin{array}{l}\text { Subdivision of } \\
\text { regional district }\end{array}$ & 2770 & 66.9 & 0 & -28.8 \\
\hline & Nelson & City & 9143 & 52.8 & 5.5 & -28.2 \\
\hline
\end{tabular}

